$[r r q]$

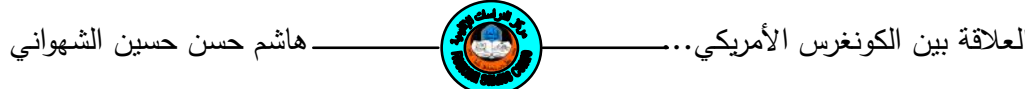

العلاقة بين الكونغرس الأمريكي والبيث الأبيض

في ظل العلاقات الخارجية

هاشم حسن حسين الثهواني

مدرس مساعد/مركز الدراسات الإقليمية/جامعة الموصل الفهرئ

مستخلص البحث

حلدت العلاقة بين الكونغرس الأمريكي والبيت الأبيض مجموعة من العوامل منها

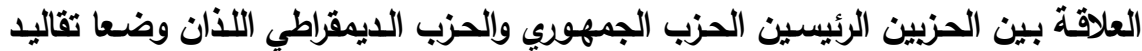

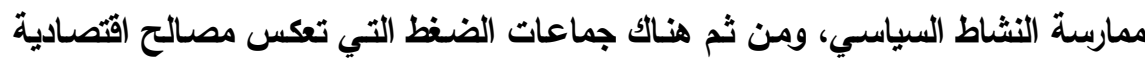

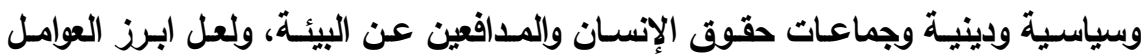

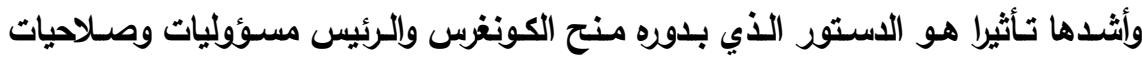

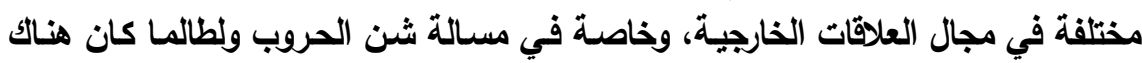

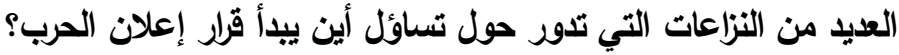

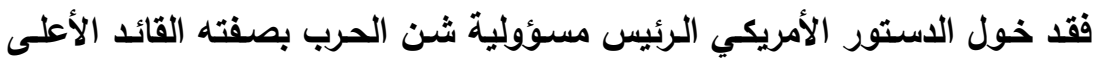

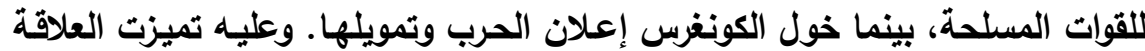

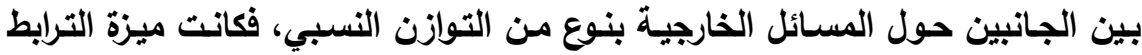
والتلازم بين قرارات الرئيس والكونغرس هي السمة البارزة.

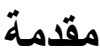

تتعكس طبيعة النظام والحياة السياسية الأمريكية على العلاقات القائمة بين

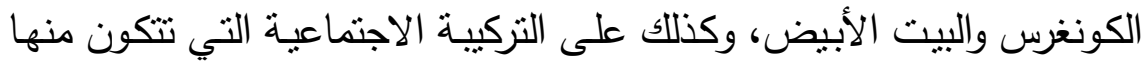

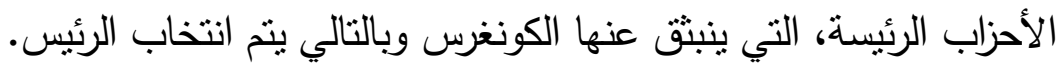

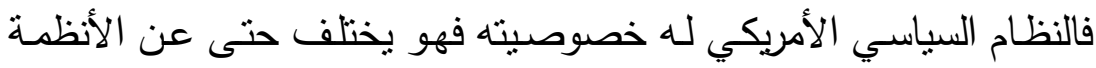

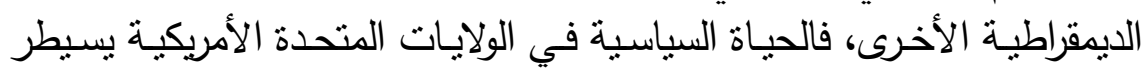

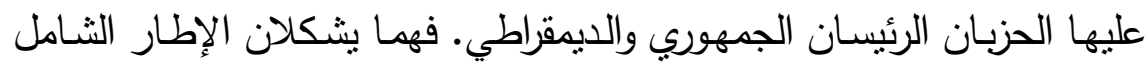

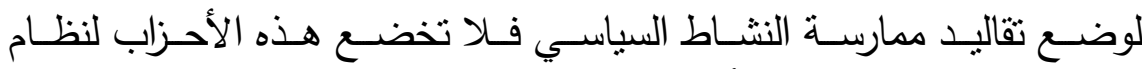

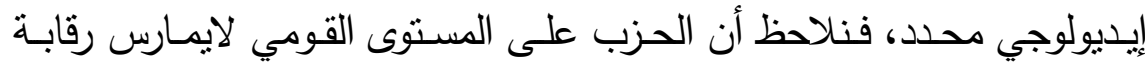




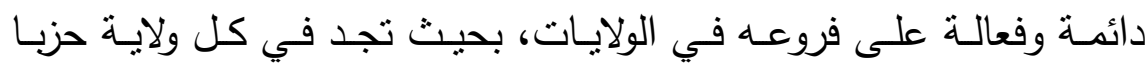

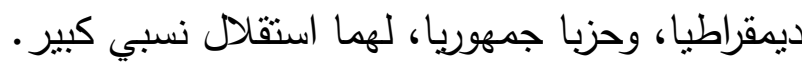

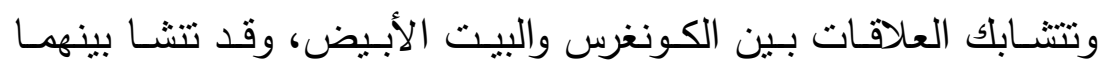

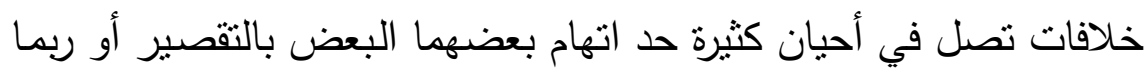

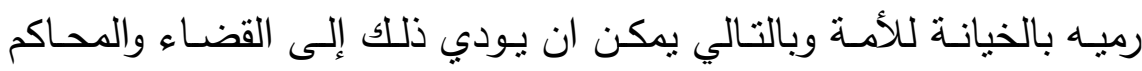
العليا، باك

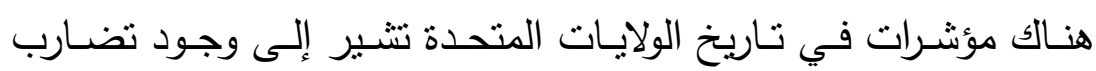

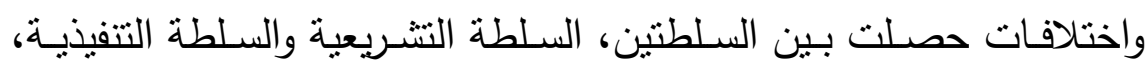

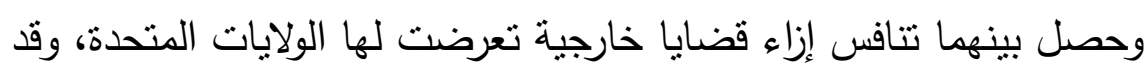

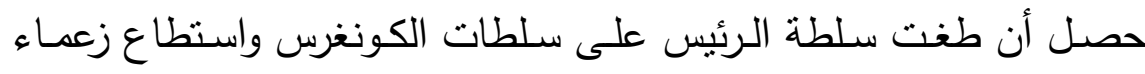

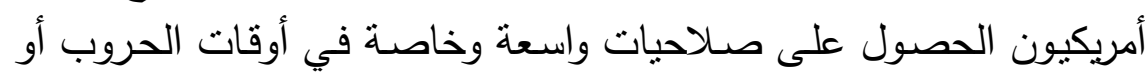

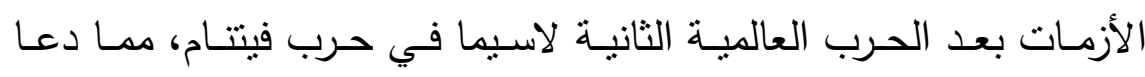

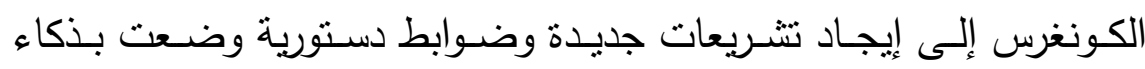

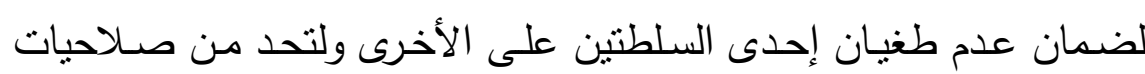
الرئيس، حتى لاتتنهي الأمور إلى انفراده في السلطة.

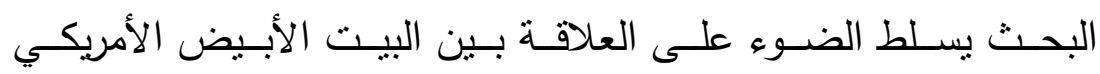

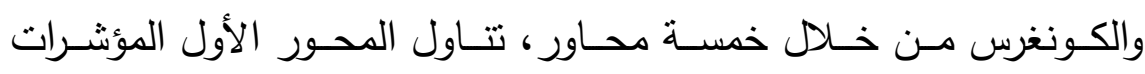

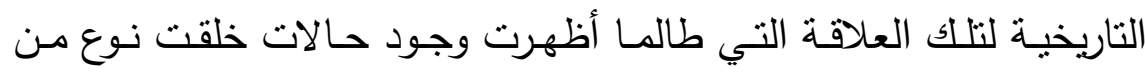

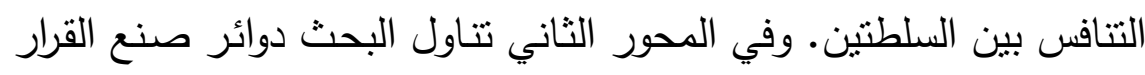

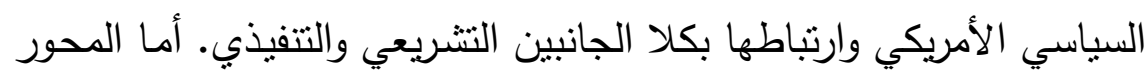

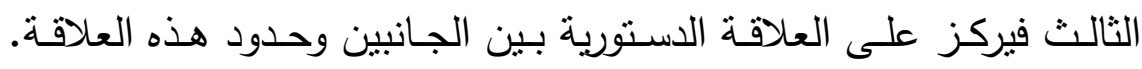

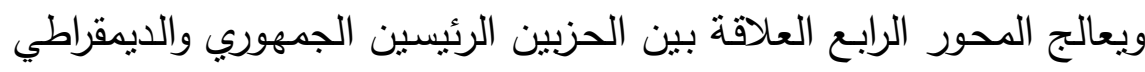

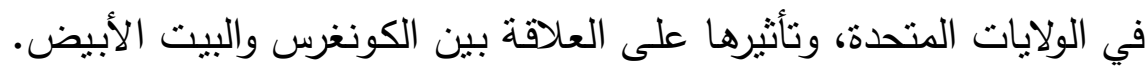

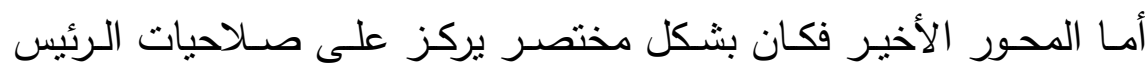

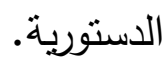




\section{الجذور التاريخية لعلاقة الكونغرس بالبيت الأبيض}

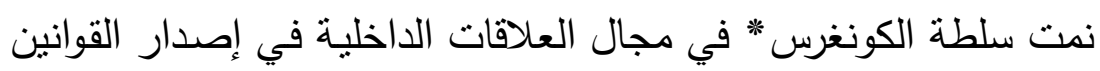

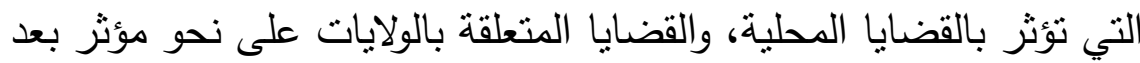

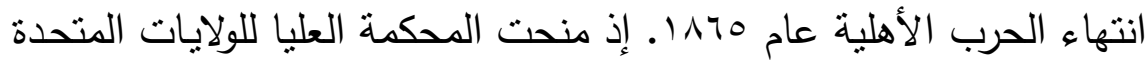

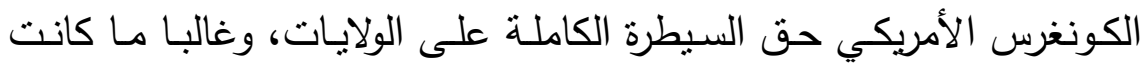

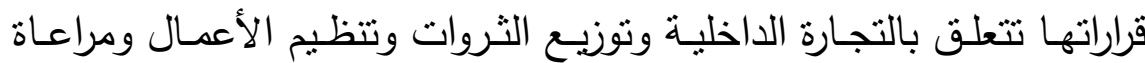

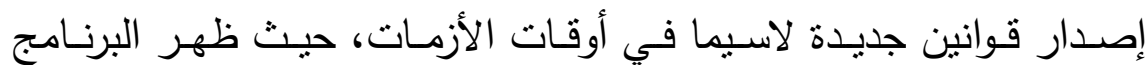
الثـامل الجديد الذي ابتكره وتبنـاه الرئيس الأمريكي (فرانكلن روزفلت الأتهات هوFranklin Roosevelt 19 19 فخلفه نائبه (هاري ترومان) Harry Truman،

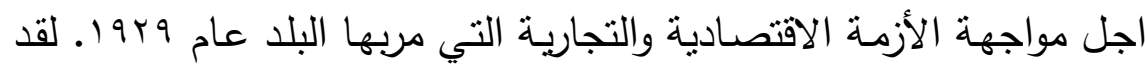

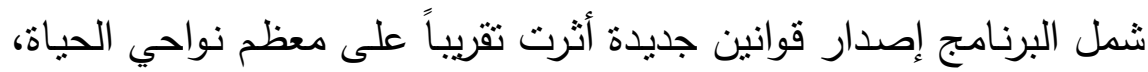

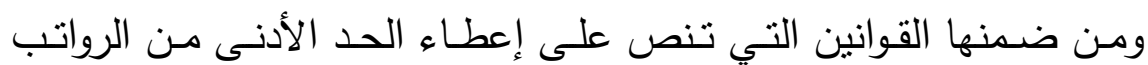

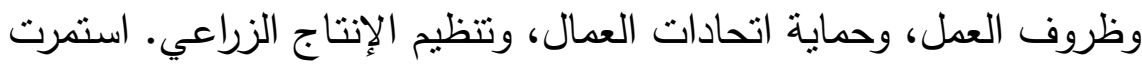

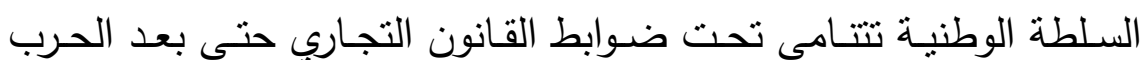

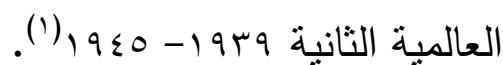

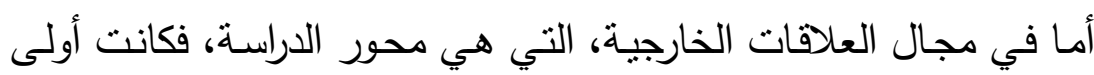

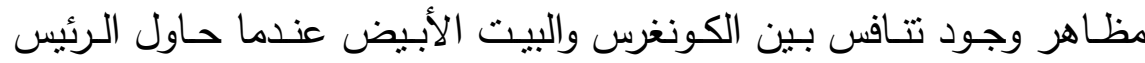

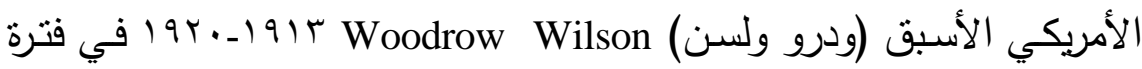

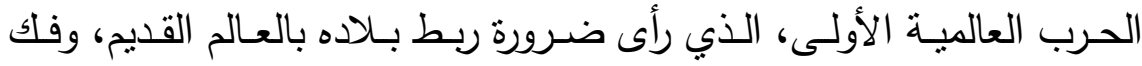

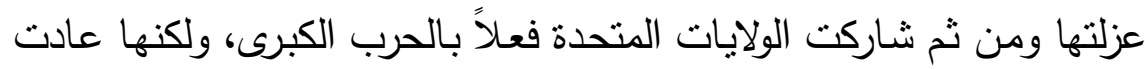

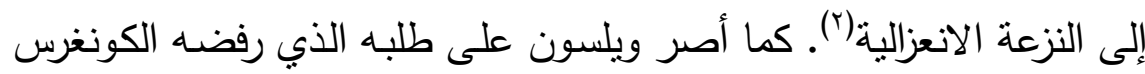

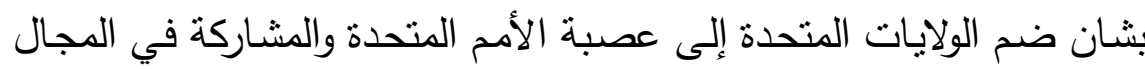

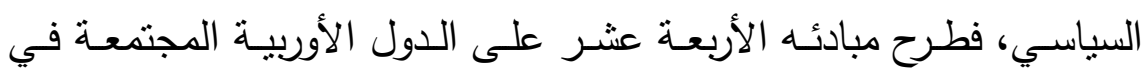




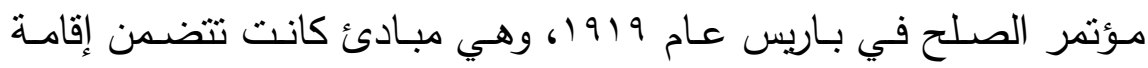

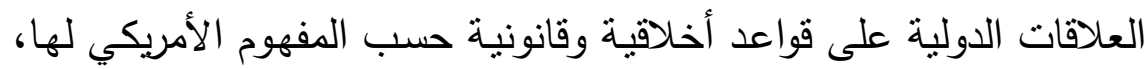

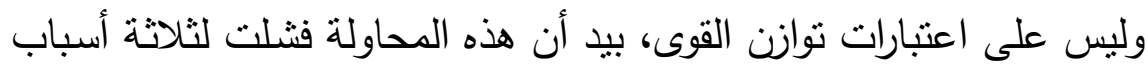

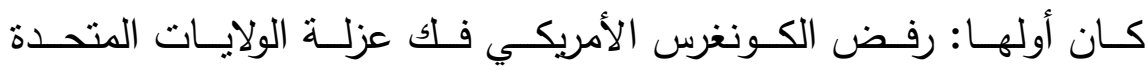

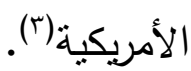

وفي فترة الثناثنينات وحتى بدايـة السبعينات مارست السـلطة التتفيذيـة

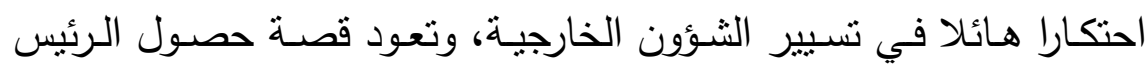

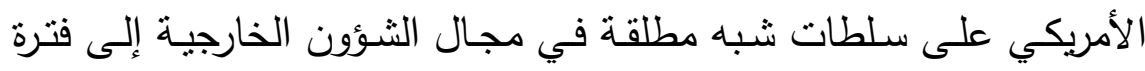

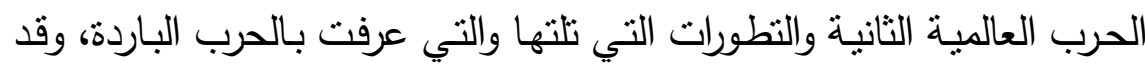

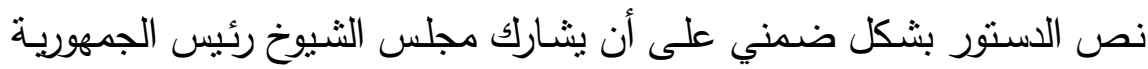

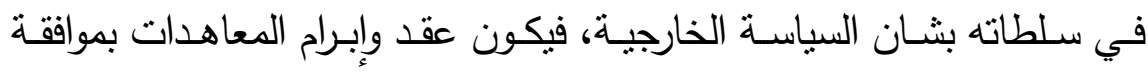

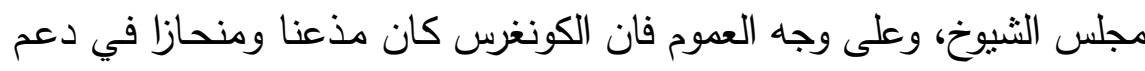

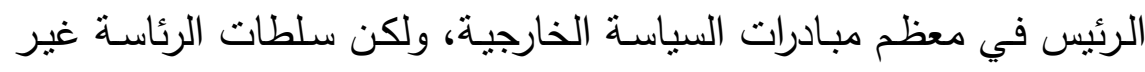

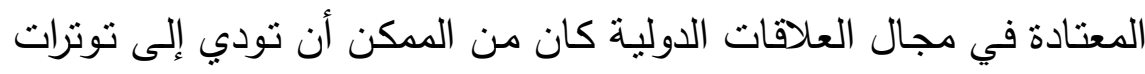

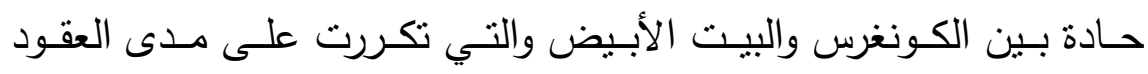

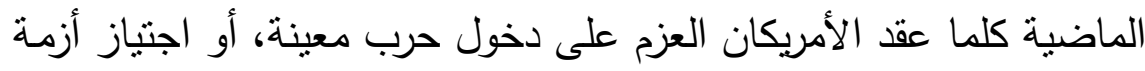

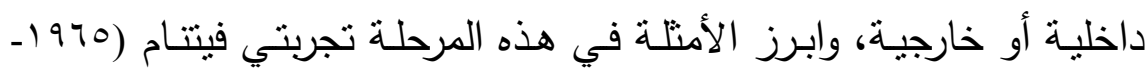

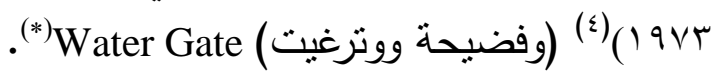

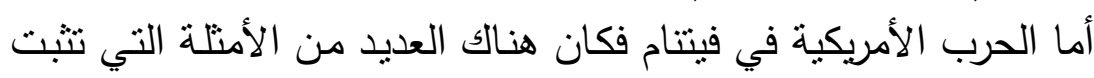

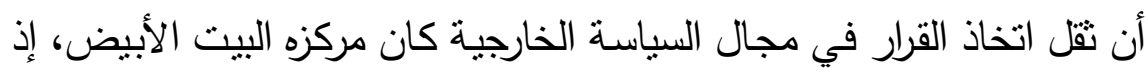

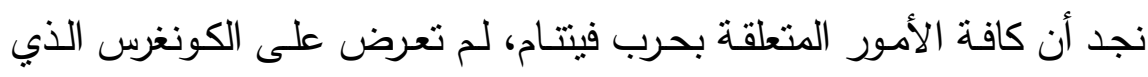

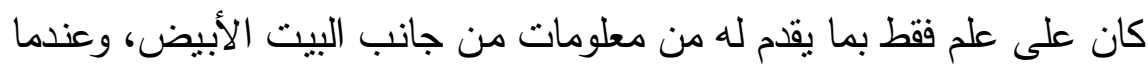

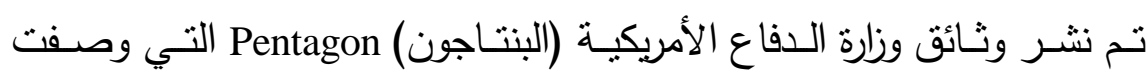

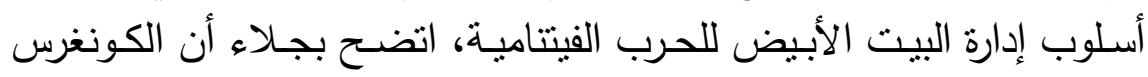

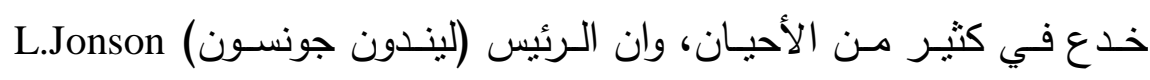


| 971 ـ 1971 قد حصل على موافقة الكونغرس لتوسيع الحرب هناك في أب|

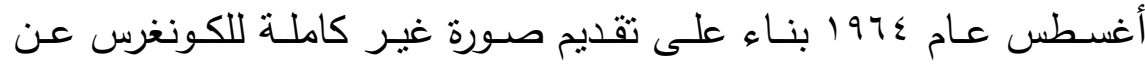

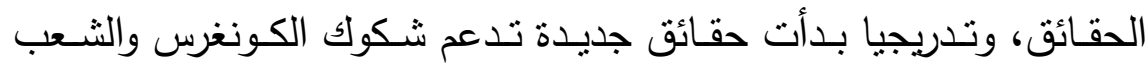

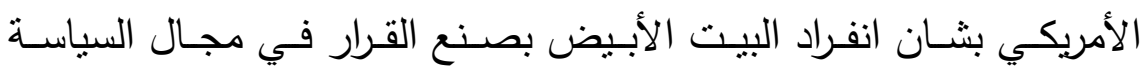

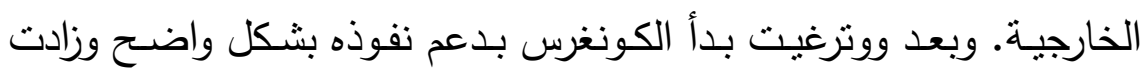

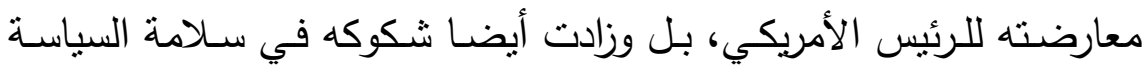

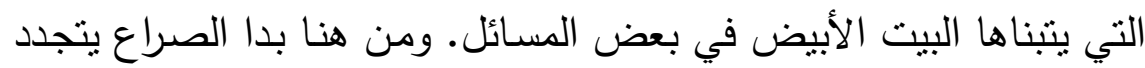
بين البيت الأبيض والكونغرس حول مصدر القرار في السياسـة الخارجية،

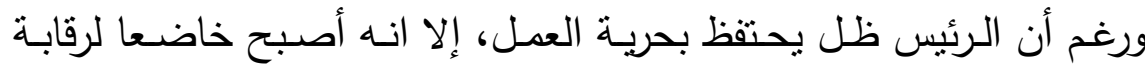

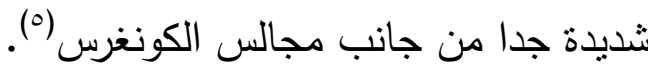

Ritchard بدا الكونغرس في عهد الرئيس الأمريكي (ريتشارد نيكسون)

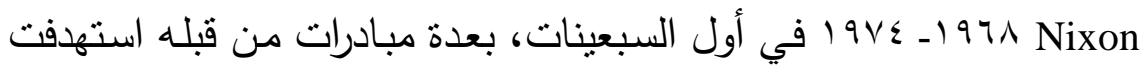

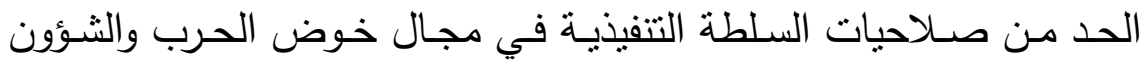
الخارجية(؟). ومن الأمور التي توخذ في الحسبان في هذه المرحلة الجديدة،

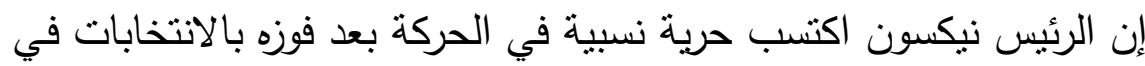

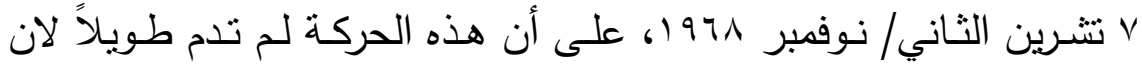
الانتخابات أسفرت عن فوز الديمقراطيين بأغلبية في مقاعد الكونغرس، مما هـاهـ

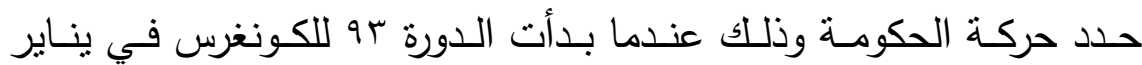
(V) ( $9 \vee r$

كان الضغط يزداد على الرئيس نيكسون داخل الكونغرس، حيث احتل

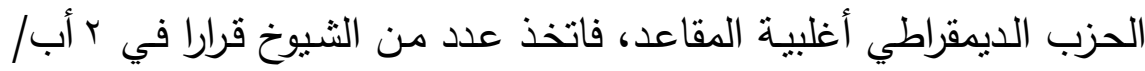

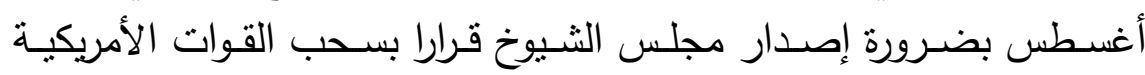

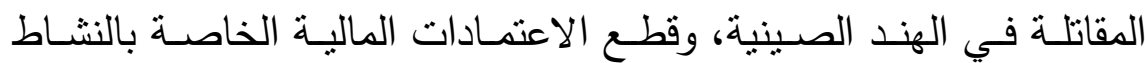
العسكري هناك في مهلة ثلاثة شهور شرط تحقيق أمرين: 
أولا: أن تطلق فيتتام الثمالية سراح جميع أسرى الحرب الأمريكيين.

ثانيا: أن توضح فيتتام الثمالية مصير المفقودين الأمريكيين (^).

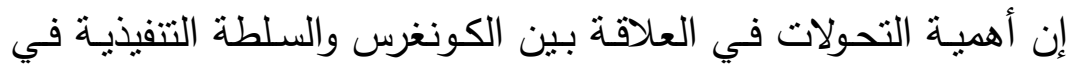
انتخابات تلك الفترة تكمن أهميتها في ثلاث مسائل:

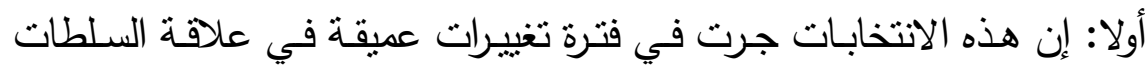
بعضها ببعض، ونعني بذلك السلطة التتفيذية والسلطة التشريعية. ثانيـا: إن هنـاك منافسـة شـديدة بـين رئسيس الجمهوريـة (السـلطة التففيذيـة)

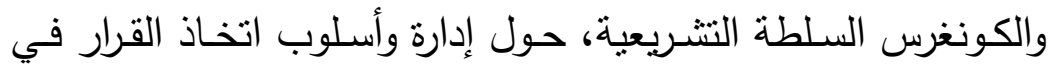
الثـؤون الخارجيـة، إذ يسعى الكونغرس إلى استعادة كافـة السلطات

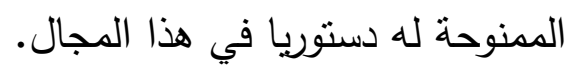

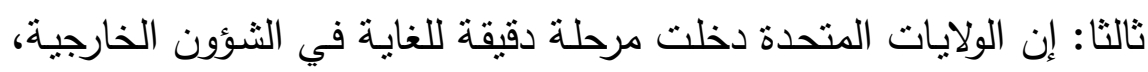
بسبب حجم وأهمية مصالحها والنزاماتها الدولية(9).

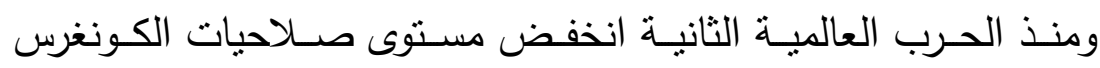
بصورة عامة في الثؤون الخارجية وارتقعت وتيرة تدخل الرئيس ومسنتـاريه

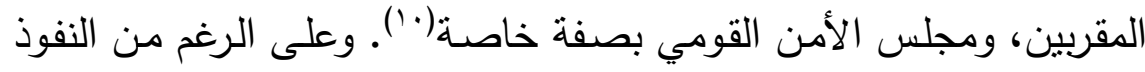
الكبير الذي يتمتع به الكونغرس على جوانب رئيسية من المعونات الخارجية ومخصصسات الأسلحة. إلا أن الأمر بلغ بالرؤساء ومسنتساريهم حدا جعلهم

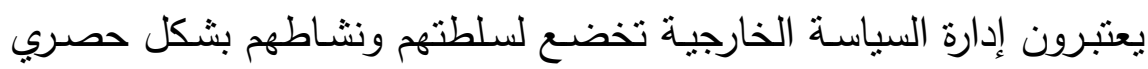

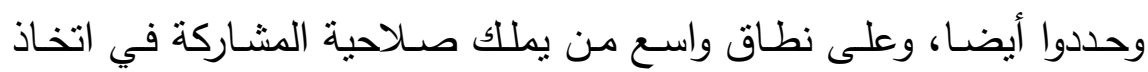
قرار التنفيذ. وبتطور موقع الرئاسـة ابـان حكم الرئيس جونسيس ونسون والرئيس

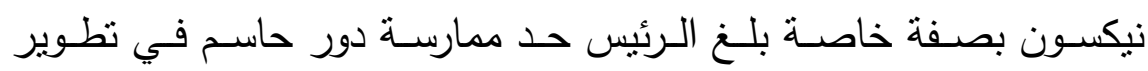

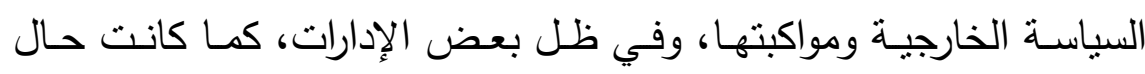

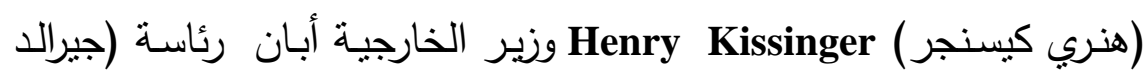
فورد)

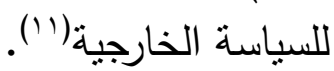


$[r r o]$

ـاشـم حسن حسين الشهواني

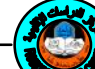
العلاقة بين الكونغرس الأمريكي.

وعلى الرغم من ان الكونغرس مارس منذ سبعينات القرن الماضي دورا

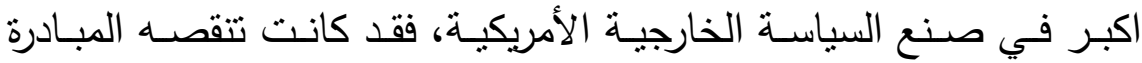

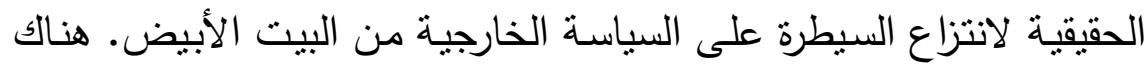
عدة أسباب وراء عجز الكونغرس عن منافسـة الرئاسـة في إدارة الثـؤون الإنس

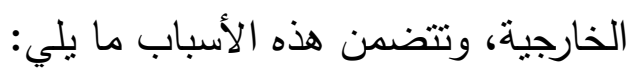
اـ احتكار السلطة التتفيذية للمعلومات في مجال الاستخبارات والدبلوماسية

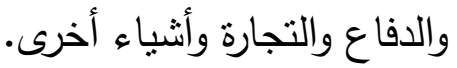

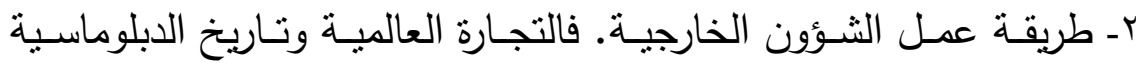
والثؤون التقافية والتقنيات العسكرية تتطلب معرفة تخصصية، والسلطة التنفيذية لديها الموارد لتوظيف الخبراء والحصول على البيانات التقنية.

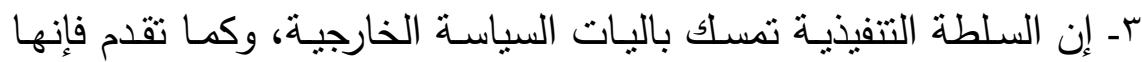

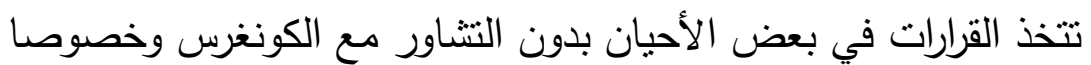

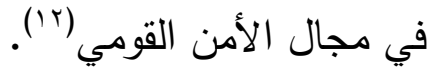
1976 Gemmy وفي كلام منسوب إلى الرئيس الأمريكي (جيمي كارنز 1980 -Carter

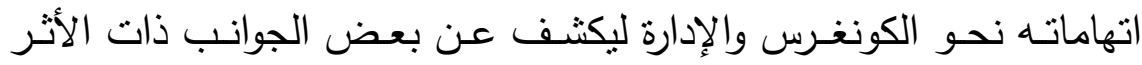

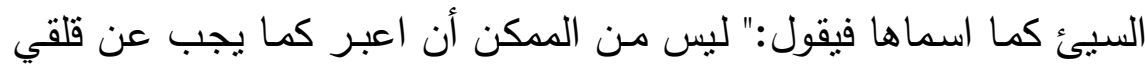

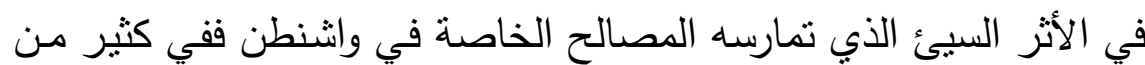

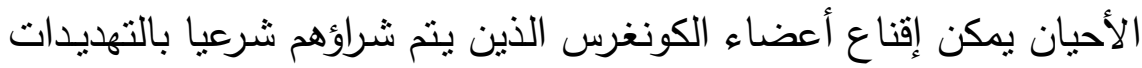

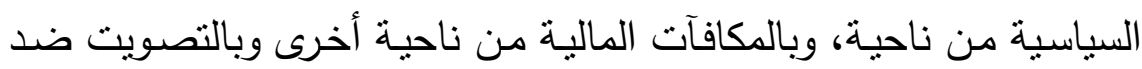

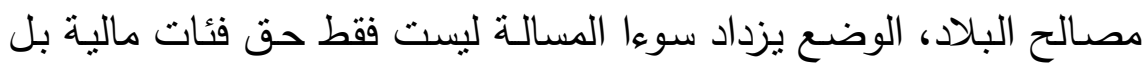

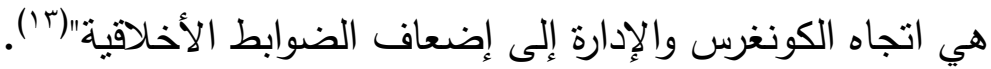


تتحدد عادة أهداف السياسـة الخارجية للدولة بما بعكس المصالح العليا

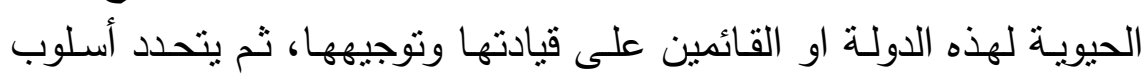

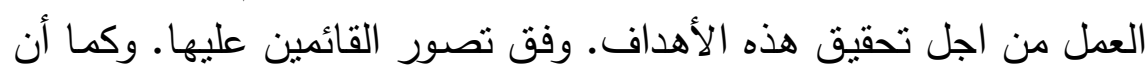

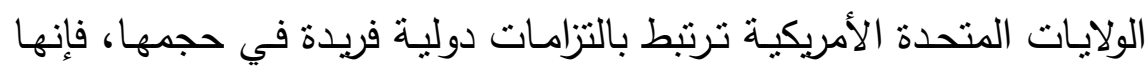

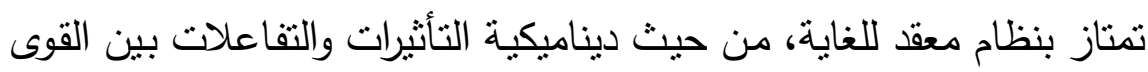

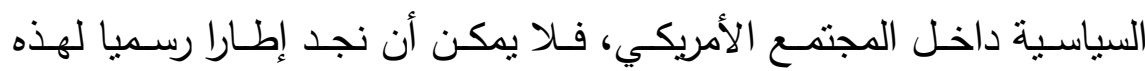

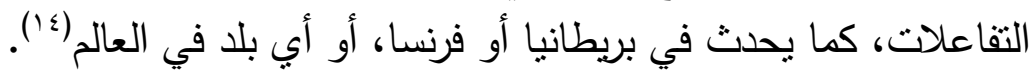

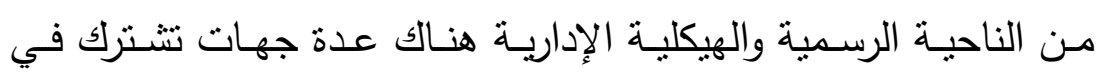

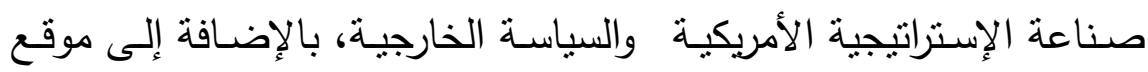

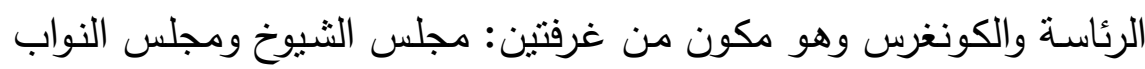

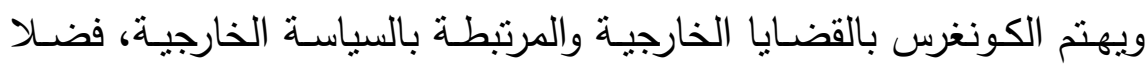

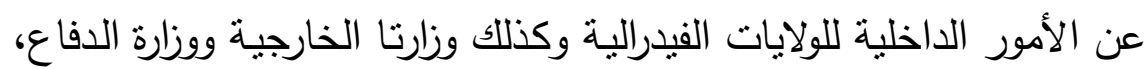
وهناك أيضا لجنة الخارجية والأمن، وهي لجنة تابعة للكونغرس، لكن الأهم من بين كل هذه الهيئات هو مجلس الأمن القومي، وهو تابع مباشرة إلى الى لإنى الرئيس الأمريكي وعادة ما يشغل هذا المنصب اقرب المقربين من الرئيس مباشرة.

أما خارج الدوائر الرسمية فهناك العديد من الجمعيات والمعاهد والمراكز

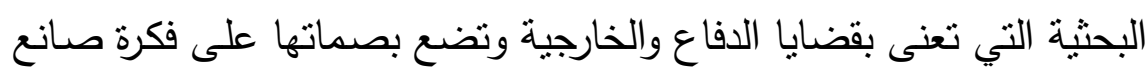
القرار، ومن بين أهم المؤسسات الفاعلة غير الرسمية نذكر : (معهد أمريكان انتربرايز) تأسس عام بـ 19 و (منتدى الشرق الأوسط)، و و (مؤسسـة برادلي)

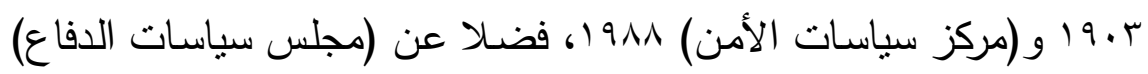

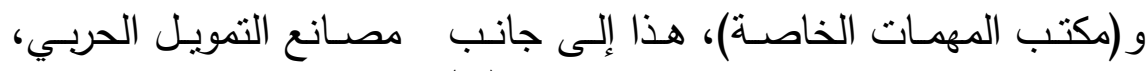
والمؤسسات الإعلامية وجماعات الكونغرس (10).

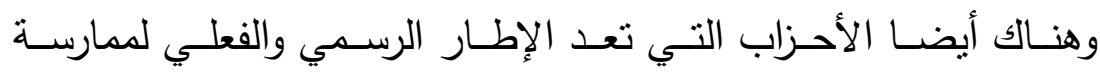
المشاركة السياسية. ويمكن القول أن الحزبين الكبيرين في الولايات المتحدة، 
هما الإطار الثـامل لوضـع تقاليد ممارسة النشاط السياسي فلا تخضـع هذه الأحزاب لنظام إيديولوجي محدد، فنلاحظ ان الحزب على المستوى القومي لايمارس رقابـة دائمة وفعالة على فروعـه في الولايـات، بحيث تجد في كل

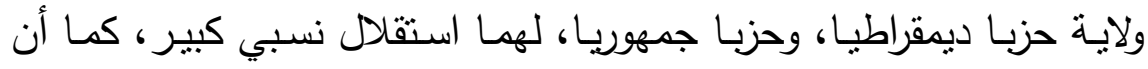

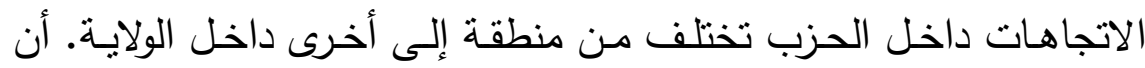

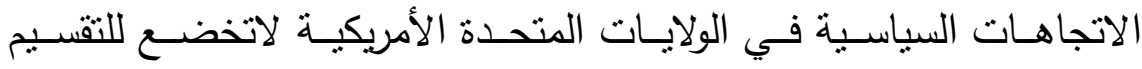

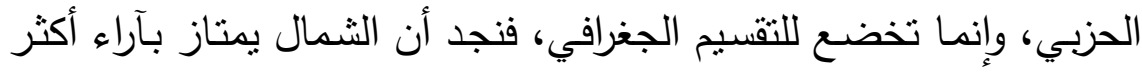
تحررا والجنوب بآراء متحفظة، وان ولايات زراعة القطن في الجنوب والوسط الجط

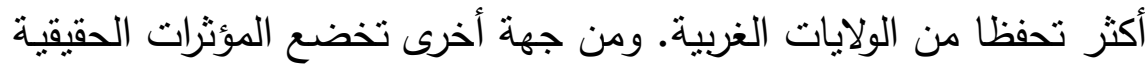

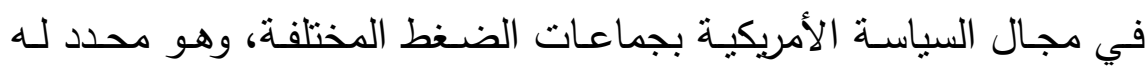
أهمية خاصة في توجيه القرار في الولايات المتحدة، وغالبها يعكس اتجاهات

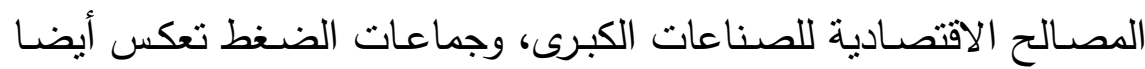

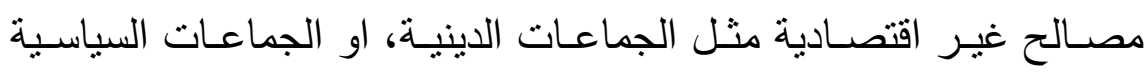
وخاصة الصهيونية، أو بعض الجماعات التي تدافع عن حقوق الإنسان، أو أو حماية البيئة(1) (17).

وهـذه الجماعـات تسـتطيع أن تـؤثز على مجريـات الأمسور مـن خـلال

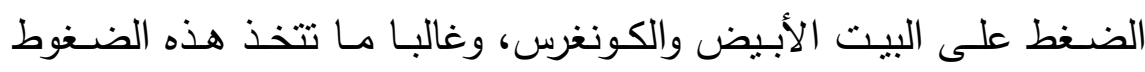
إثكالا مختلفة تتراوح ما بين تأثير الصوت الانتخابي، وتأثنير المساعدات

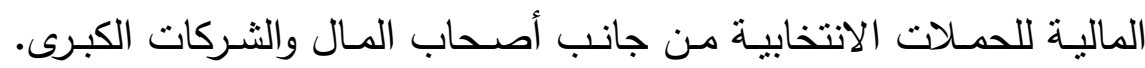

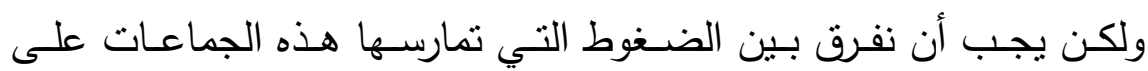
الكونغرس، وعلى البيت الأبيض والتفرقة تجرنـا إلى مسائل دقيقة ومعقدة، تتعلق بنظم التأثير على اتخاذ عضو مجلس الثيخ وعضو مجلس النواب

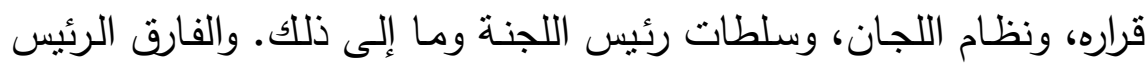

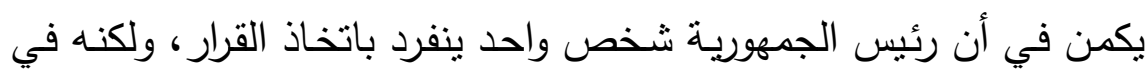

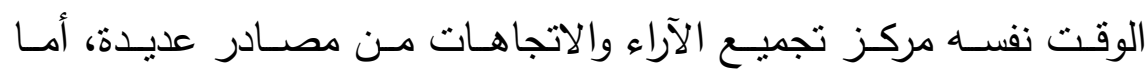


الكونغرس فيضم عدد كبير جدا من الأعضاء، وكل عضو لله صوت يعتد

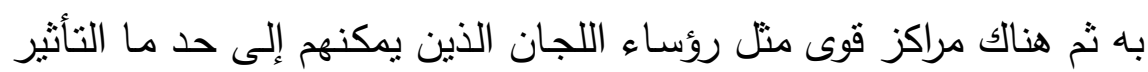

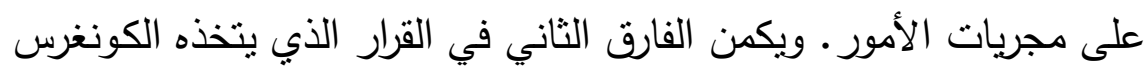

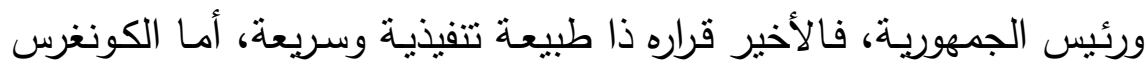

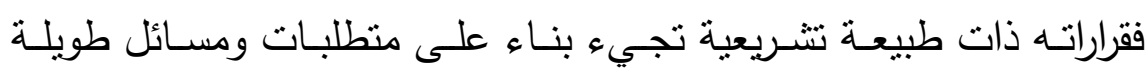
الأجل، ماعدا بعض الأمور العاجلة التي يعرضها رئيس الجمهورية، او كرد

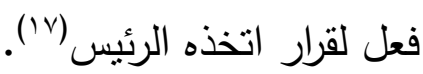

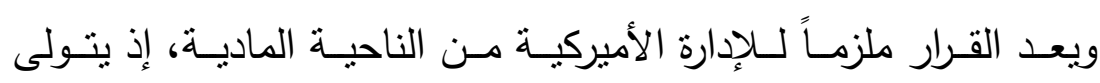
الكونغرس حق تمويل المشـاريع العسكرية أو رفضها. وجاء في القرار الذي لئي

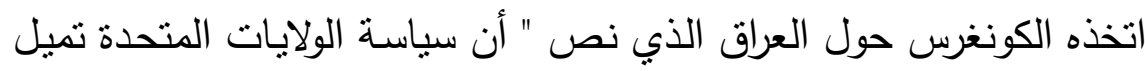

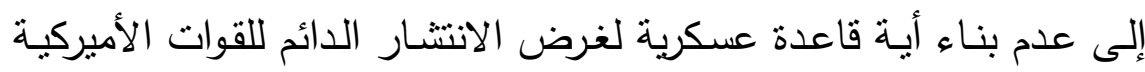
المسلحة في العراق". ولفت القرار إلى تصريحات الرئيس الأميركي (جورج

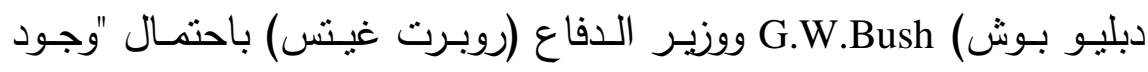

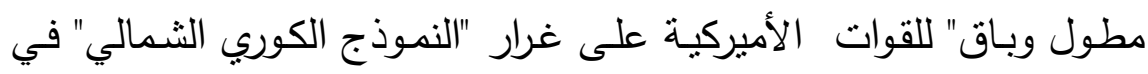

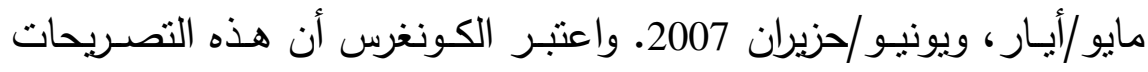

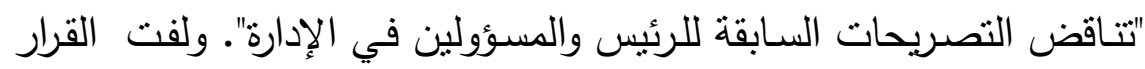

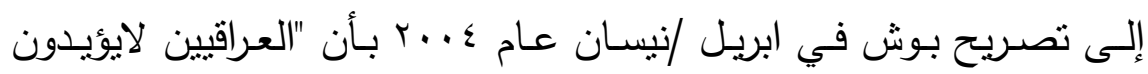

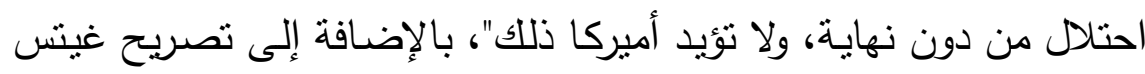

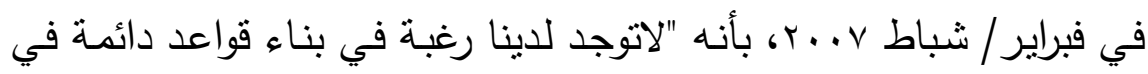

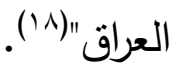


[rra]

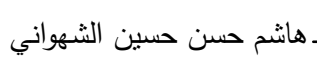

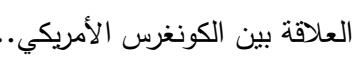

فنح الدستور الأمريكي الكونغرس والرئيس مسؤوليات وصلاحيات مختلفة

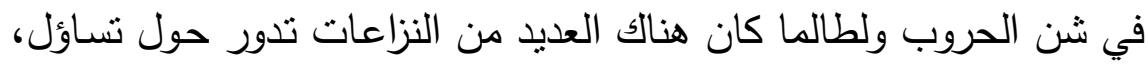

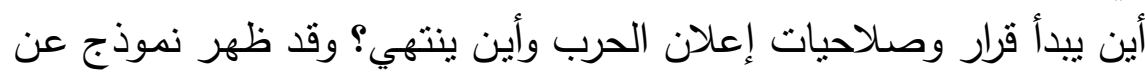

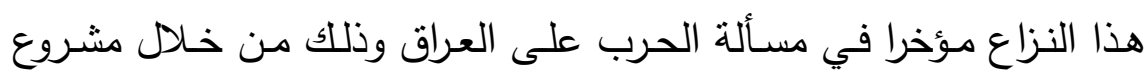

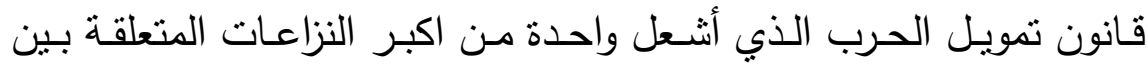

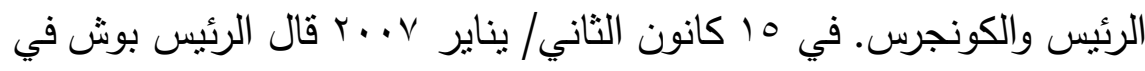

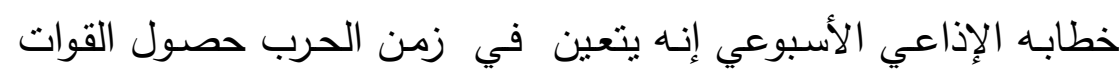

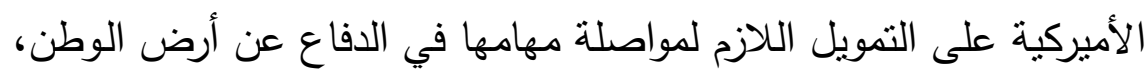

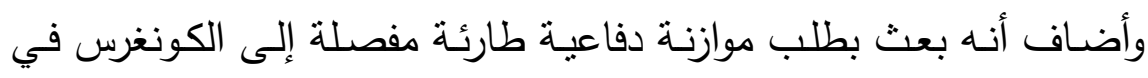

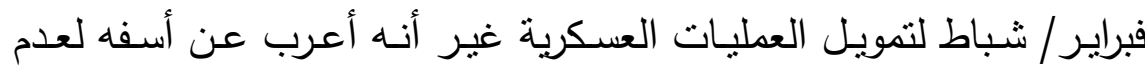

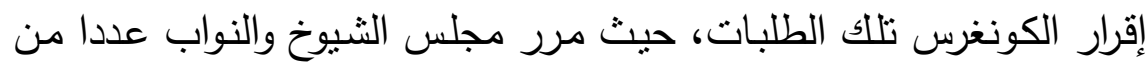

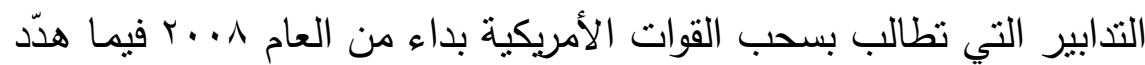

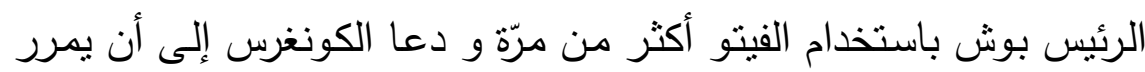

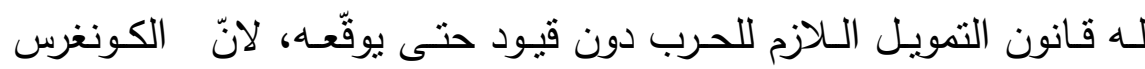

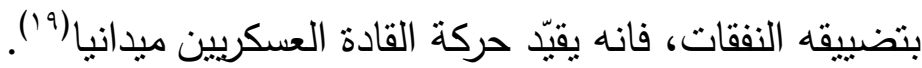

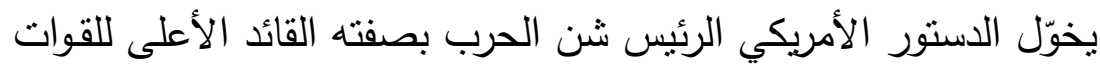

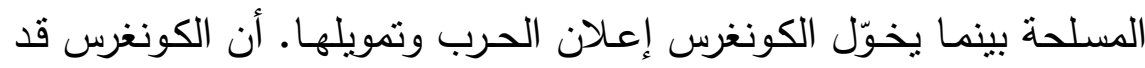

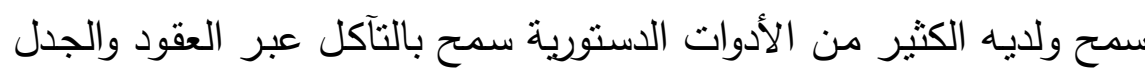

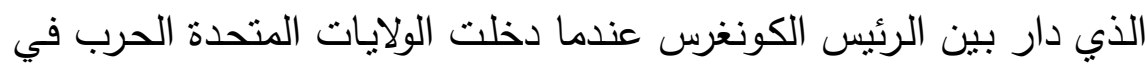

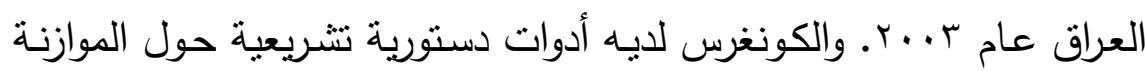

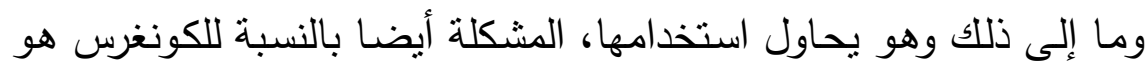

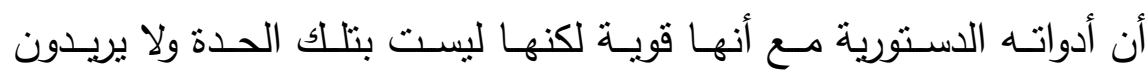

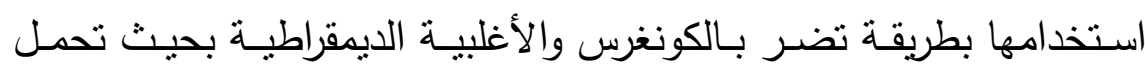

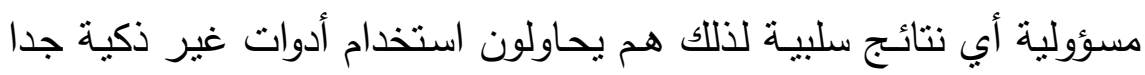


لإجبار الرئيس على التفاوض بسياسة مختلفة جديدة للعراق تنطوي على الإسى بعض التخفيض للقوات الأميركية هناك (r.r).

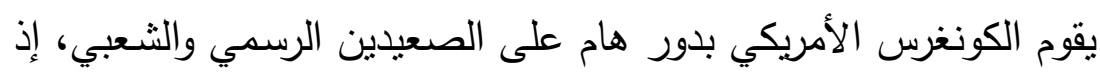

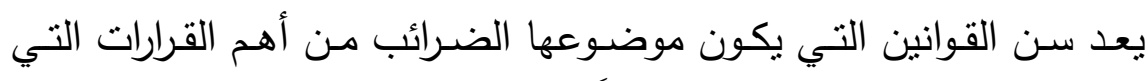

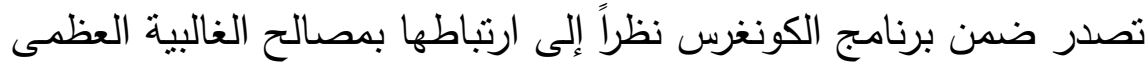

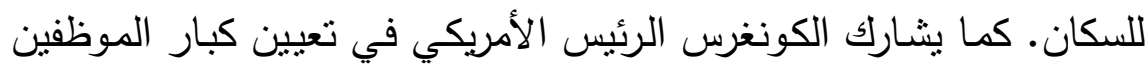

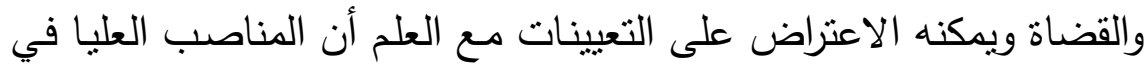

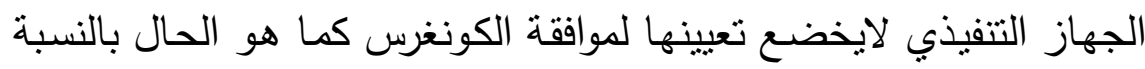

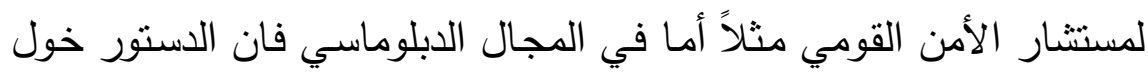

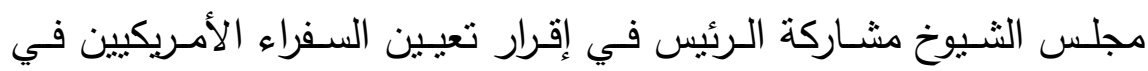

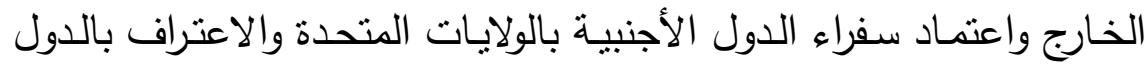

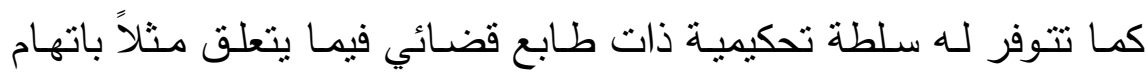

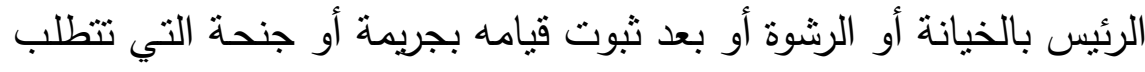

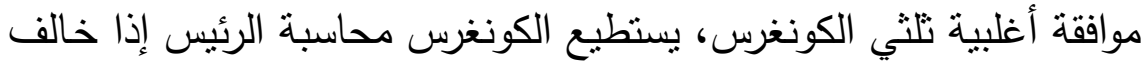

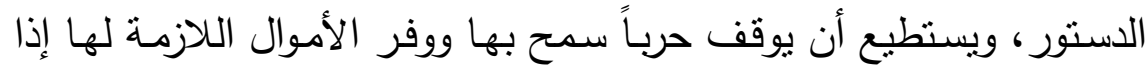

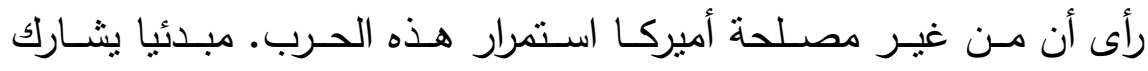

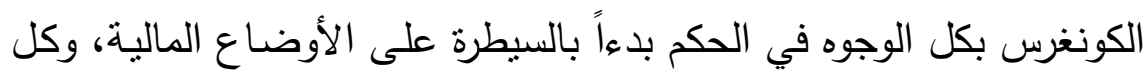

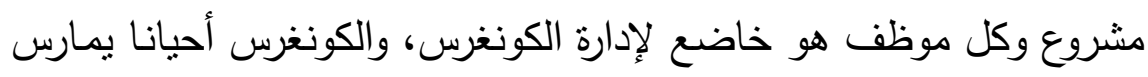

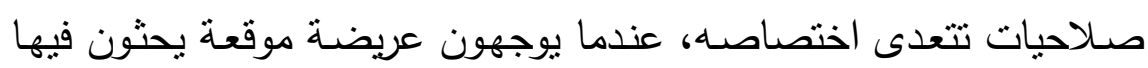

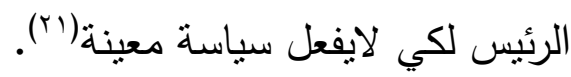
أن قدرة الكونغرس الأميركي على الحد من العملية العيات العسكرية الأميركية

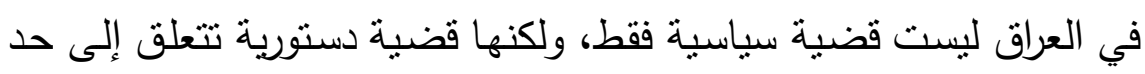

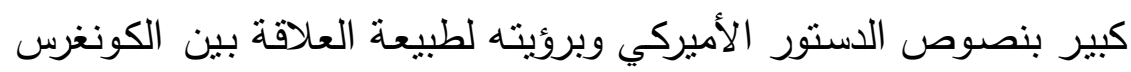

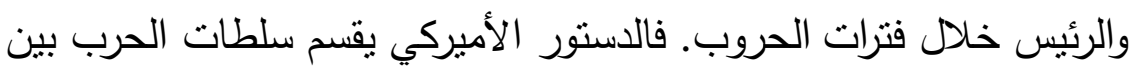

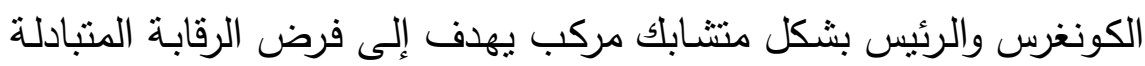




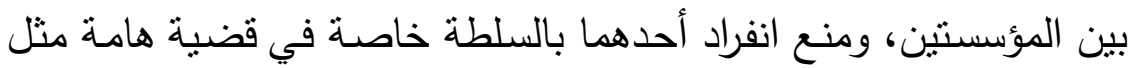

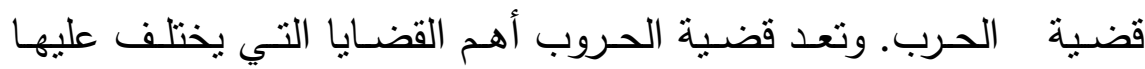

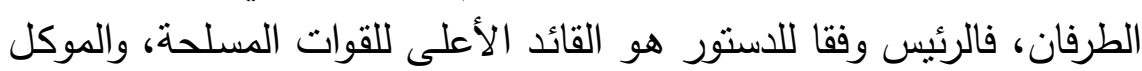

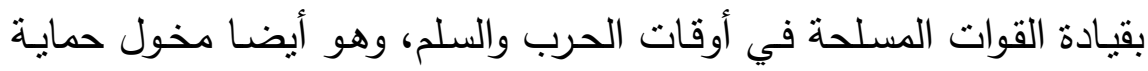

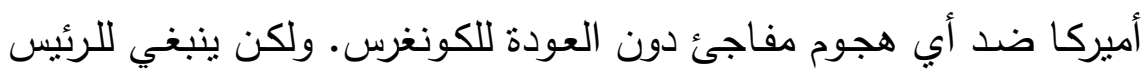

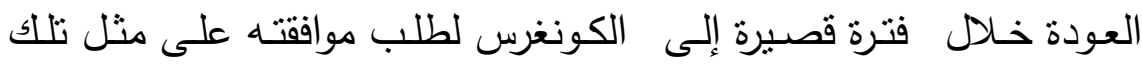

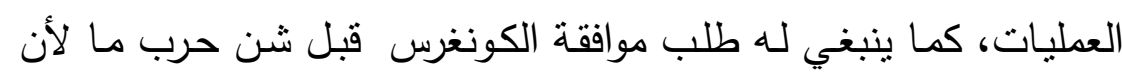
الكونغرس يمتلك سلطة إعلان الحرب وتمويلها، بينما يملك الرئيس سلطة

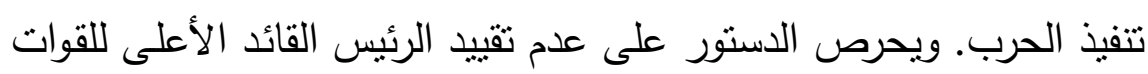

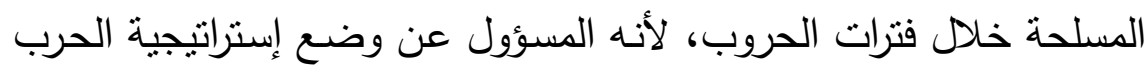

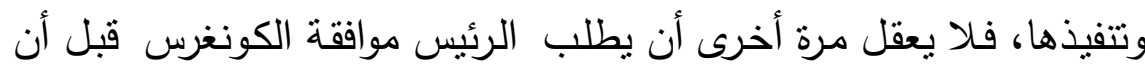

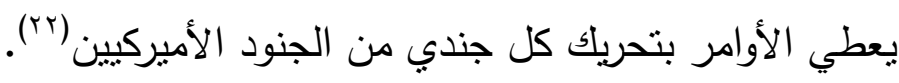

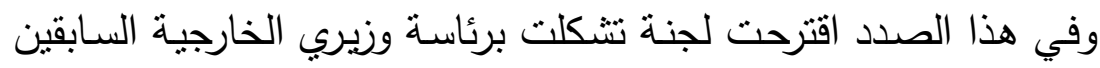

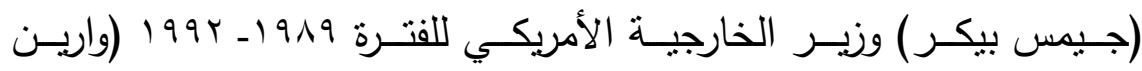

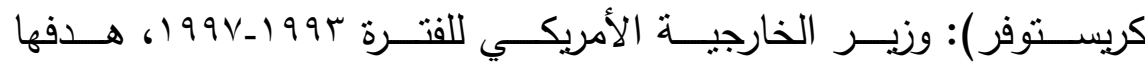

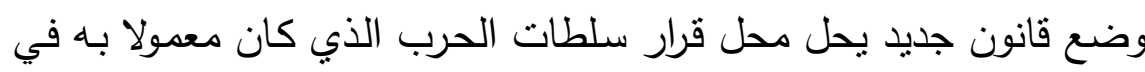

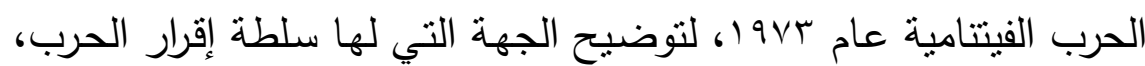

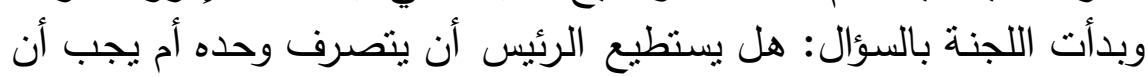

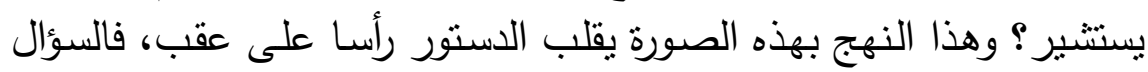

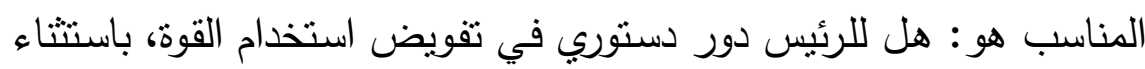

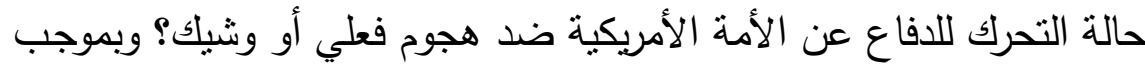

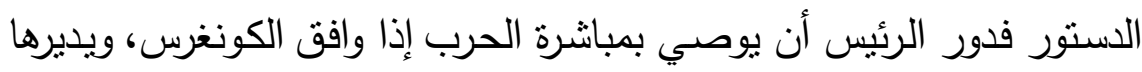

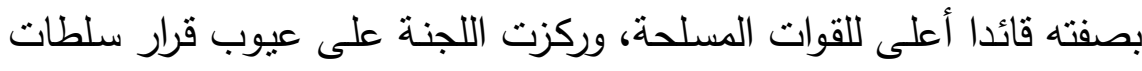

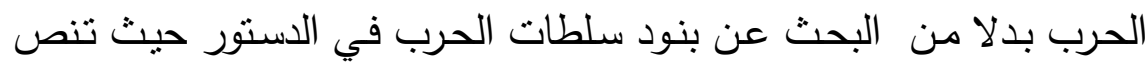
المادة الأولى والثانية: أن الكونغرس وحده لـه سلطة إقرار شن الحرب لتحن وتحديد 
متى يكون ذللك، أما الرئيس فله وحده سلطة إقرار كيفية شن تلك الحرب. ومنح سلطة إقرار الحرب للسلطة التثريعية ومباثرة الحرب للسلطة التنفيذية كان التهان

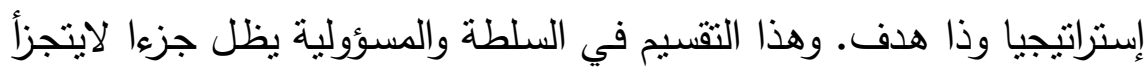

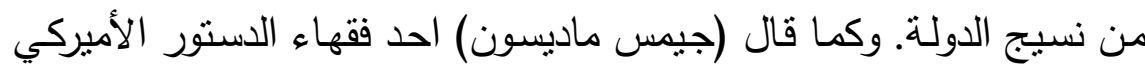

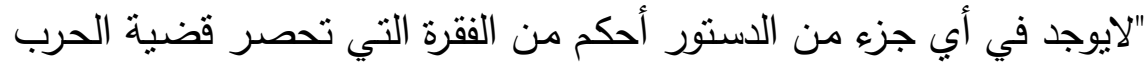

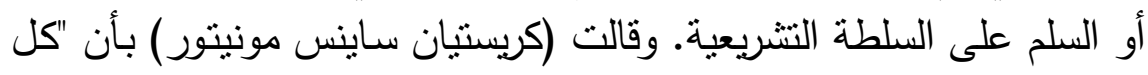

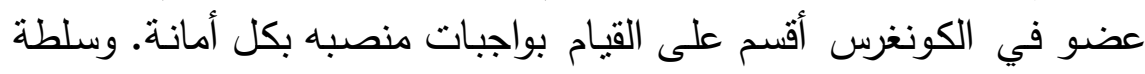

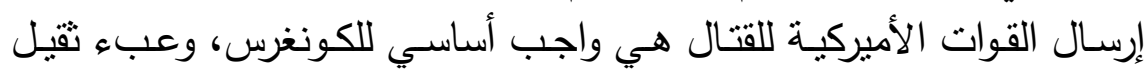

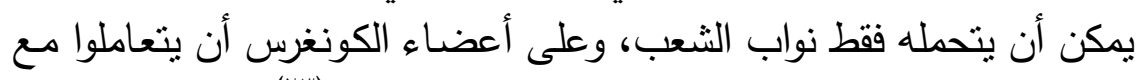

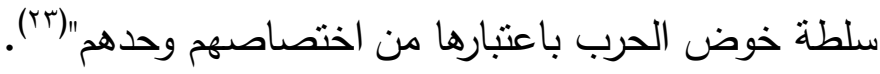

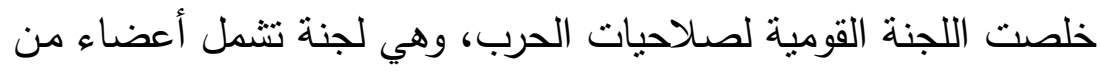

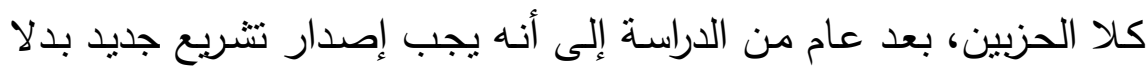

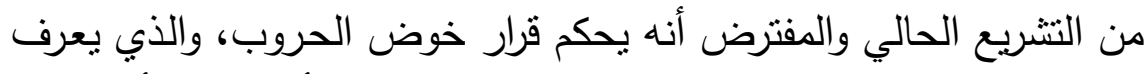

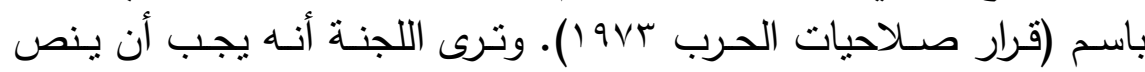

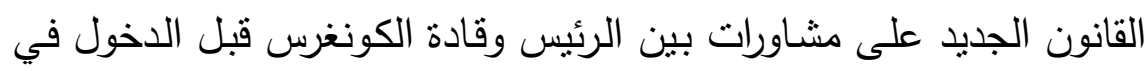

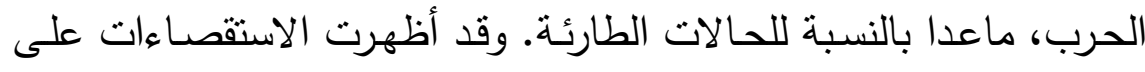

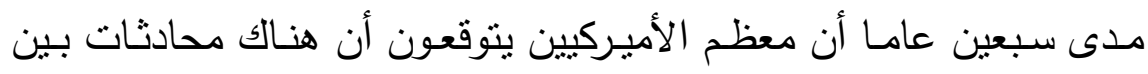

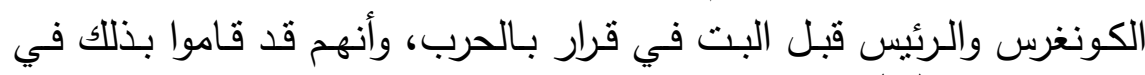

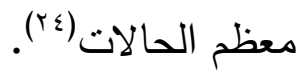

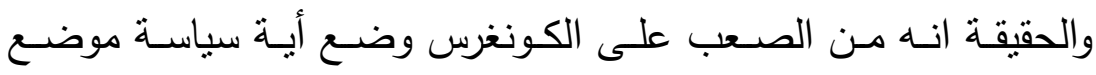

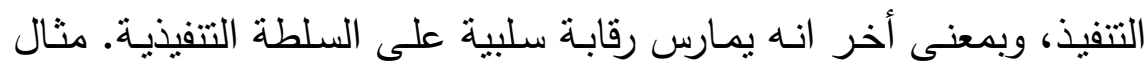

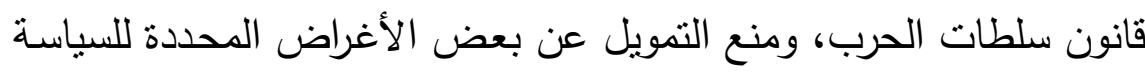

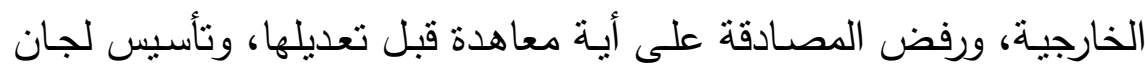

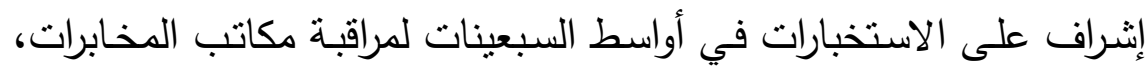

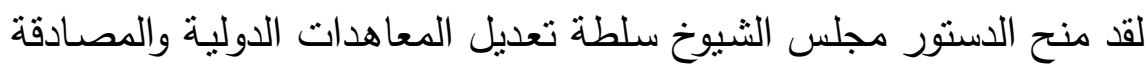

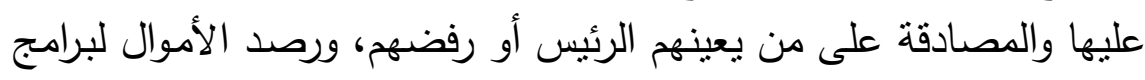


$[r \leqslant r]$

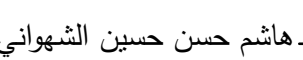

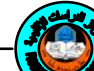
العلاقة بين الكونغرس الأمريكي.

السياسة الخارجية. وفي الحقيقة فانه من خلال سلطاته في تنريع القوانين

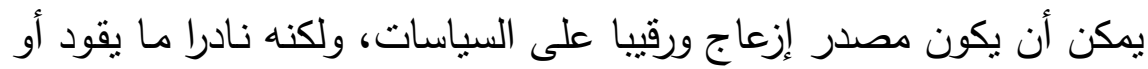

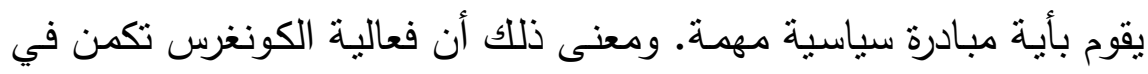

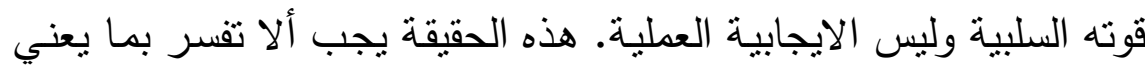
أن الكونغرس ليس طرفا مها في الثؤون الخارجية (ب0).

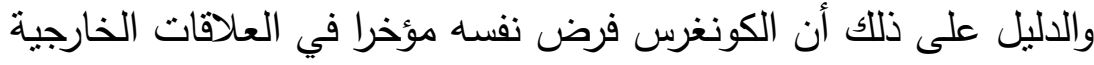

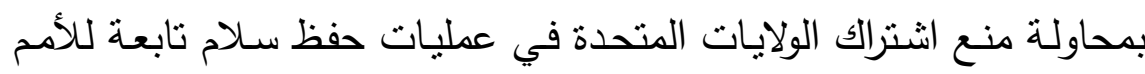
المتحدة والتسريع بتوسيع حلف شمال الأطلسي (الناتو) NATO إلى بلدان

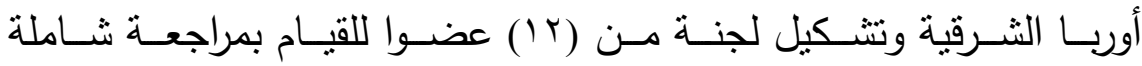
لاحتياجات الأمن القومي البعيدة المدى للولايات المتحدة وهو تحد كبير

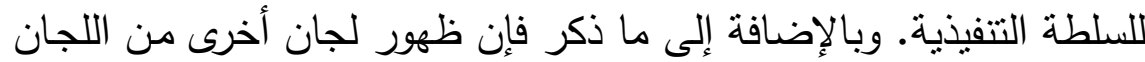

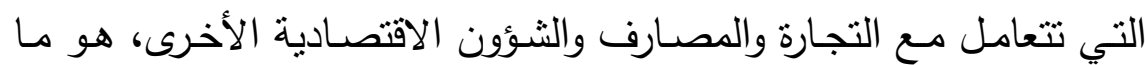

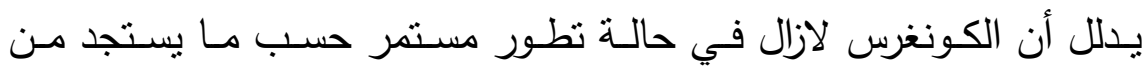

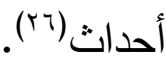

وإذا اختار مجلس الثيوخ استخدام صلاحياته كأداة مساومة، فان بإمكانه

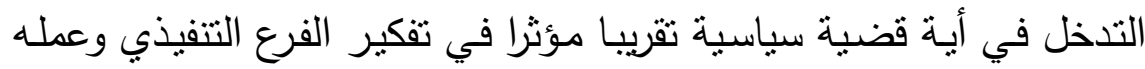

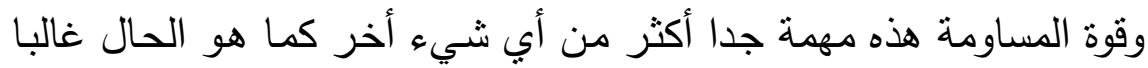

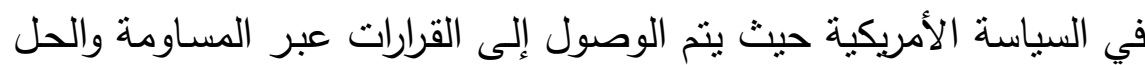

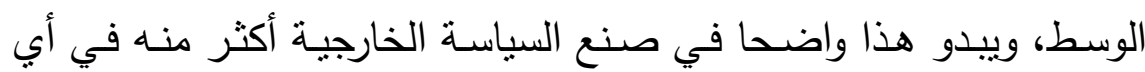

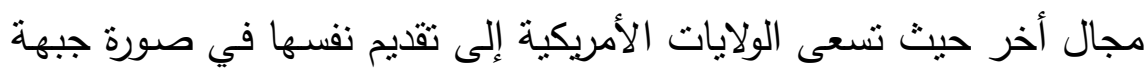

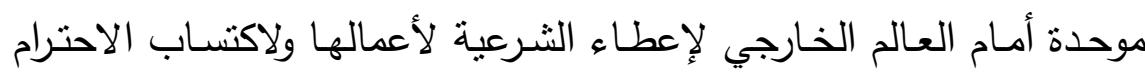

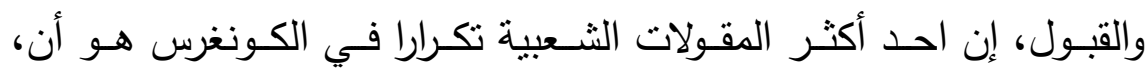

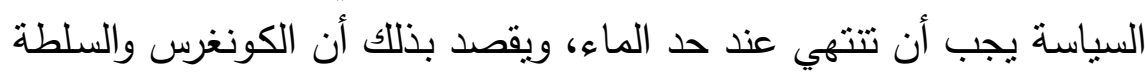

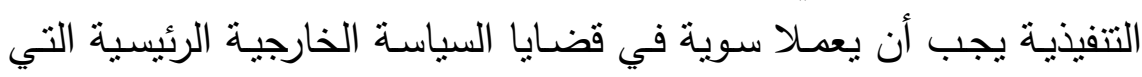

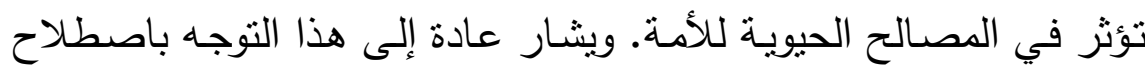


التوافق الثنائي (Bipartisanship)، وهناك اتفاق على أن المسائل المتعلقة

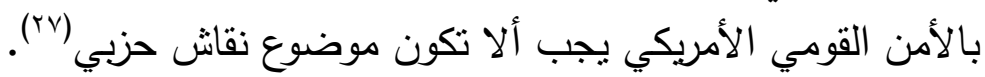

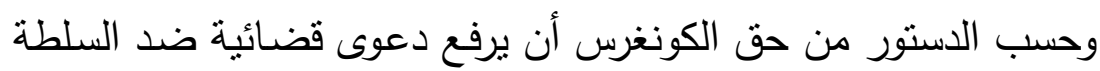

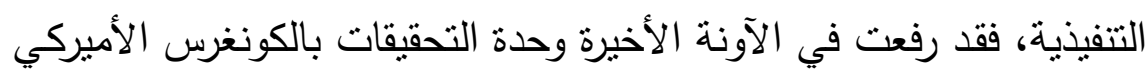

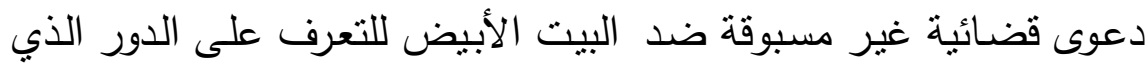

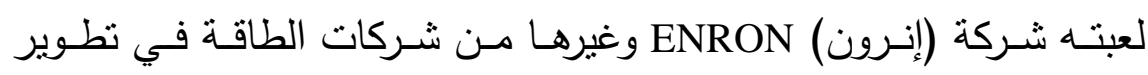

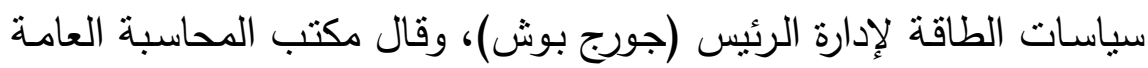

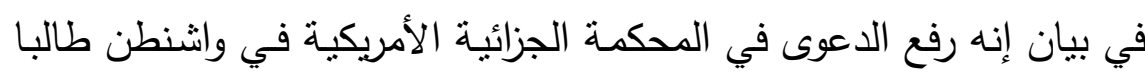

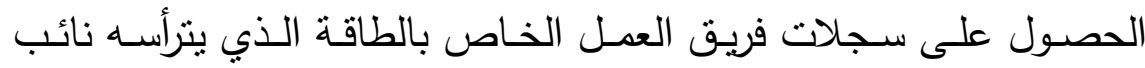

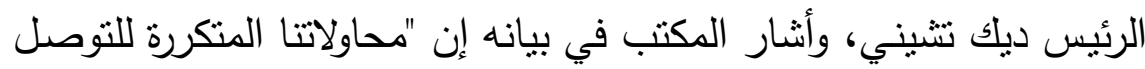

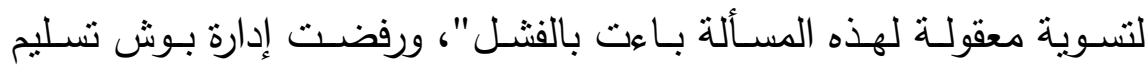

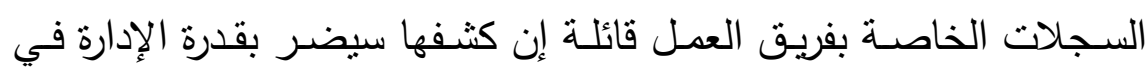

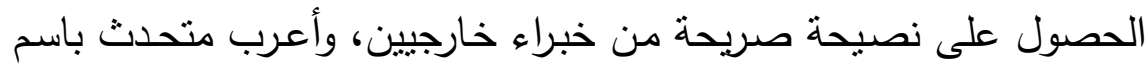

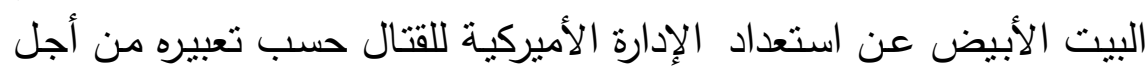

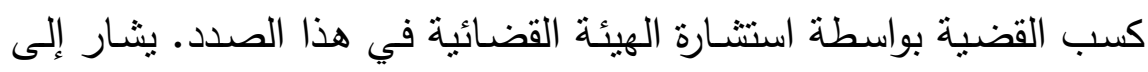

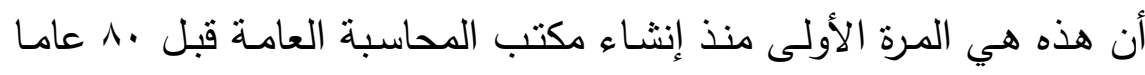
يقاضي فيها المكتب السلطة التتفيذية للحصول على وثائق، وكانت مثل هذه التهاه

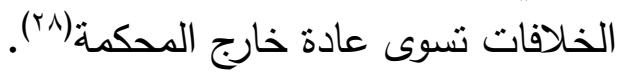

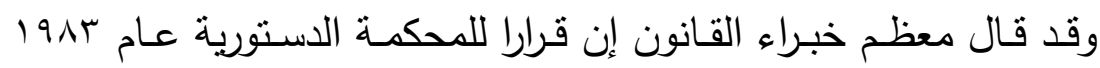

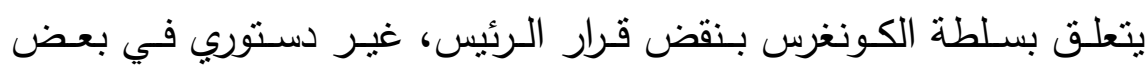

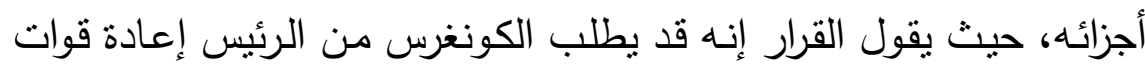

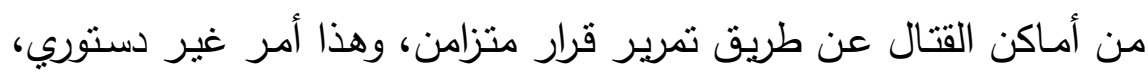

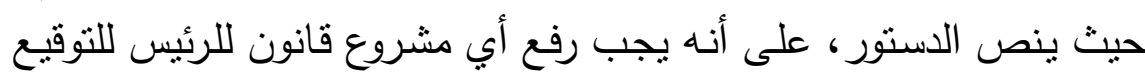

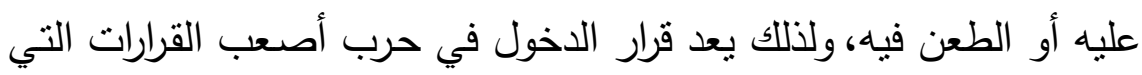

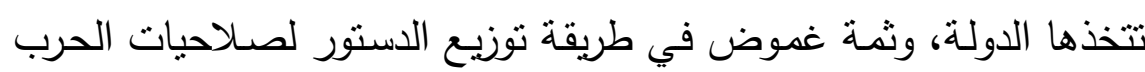


$[r \leqslant 0]$

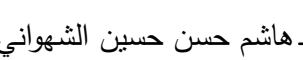

بين الرئيس (القائد الأعلى للقوات المسلحة) والكونغرس (الذي لديه حق

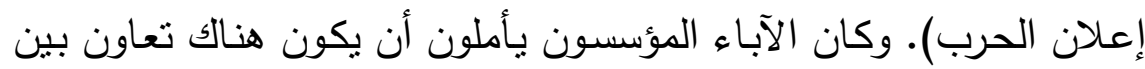

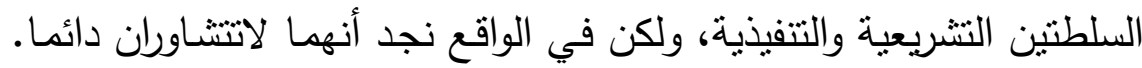

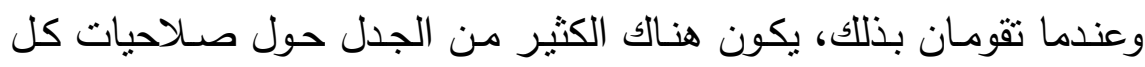

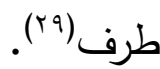

\section{العلاقة بين الحزبين الجمهوري والديمقراطي}

تختصر علاقة الكونغرس بالبيت الأبيض علاقة الحزبين الرئيسيين في الجيني

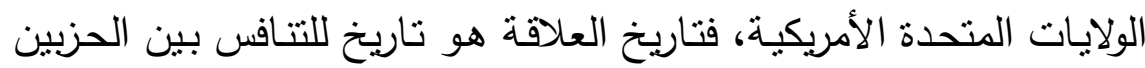

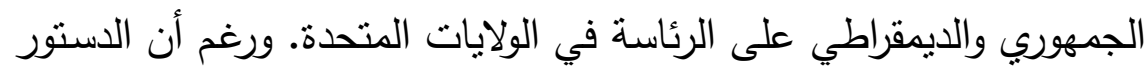

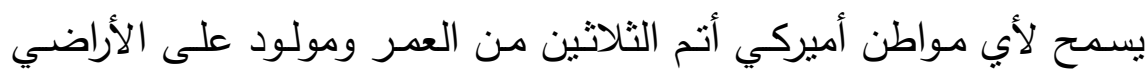

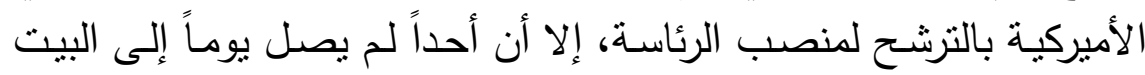

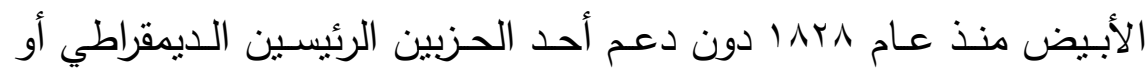

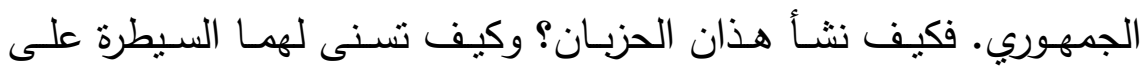

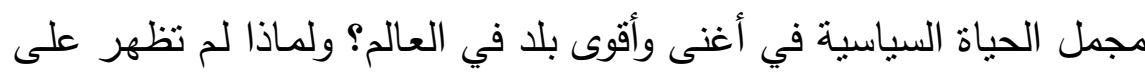

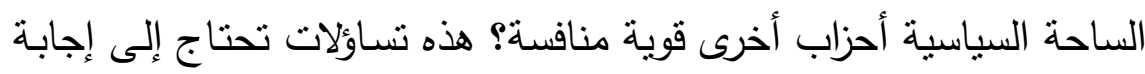

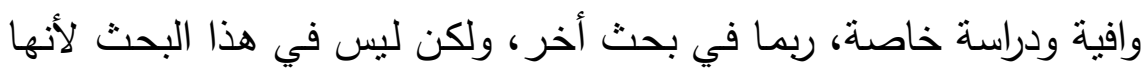

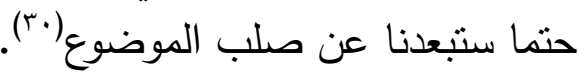

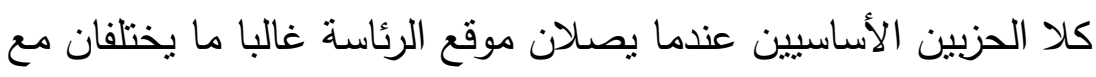

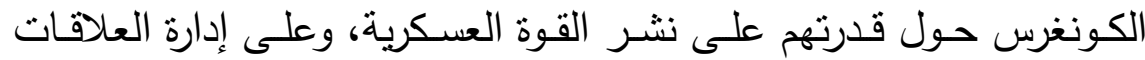

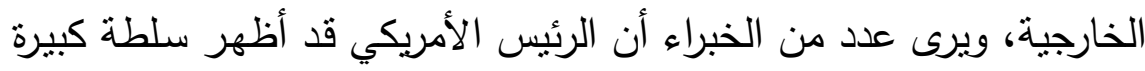

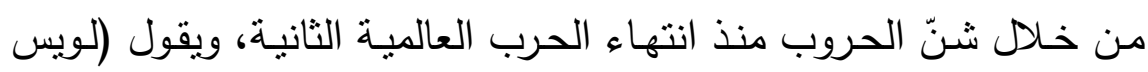

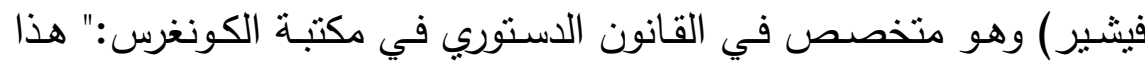

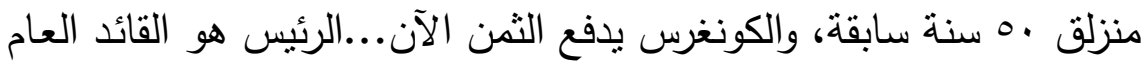

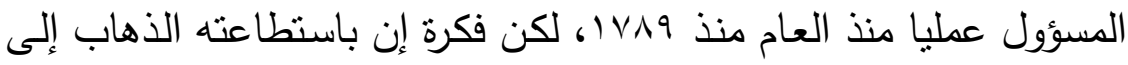


الحرب حينما يشاء متجاهلا الكونجرس قد جاءت وليدة حقبة ما بعد الحرب

العالمية الثانية("r).

وهنـاك أيضـا تبـاين بـالرأي بـين الـديمقراطيين والجمهوريين وبمـا أنسه

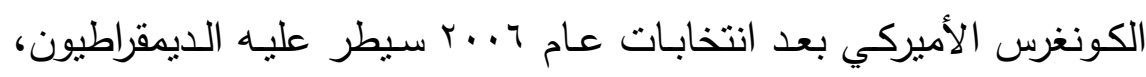

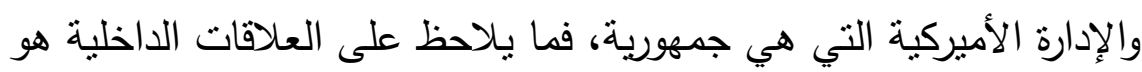

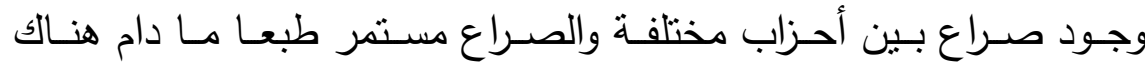

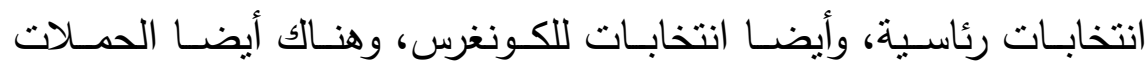

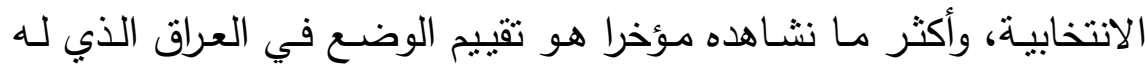

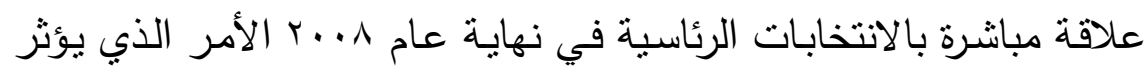

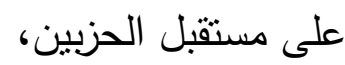
كان من أهم القضايا التي اختلف عليها الكونغرس مـع الرئيس الأمريكي

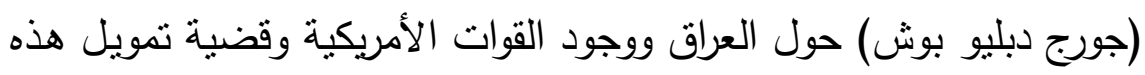

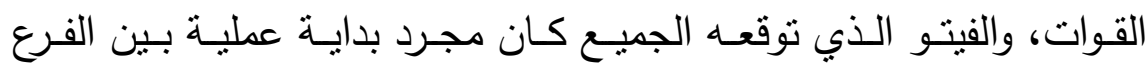

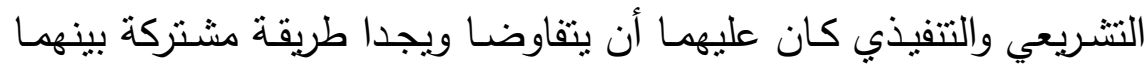

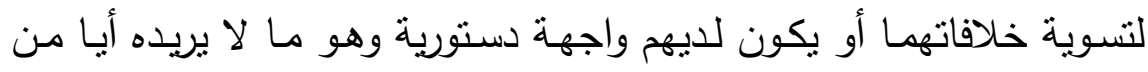

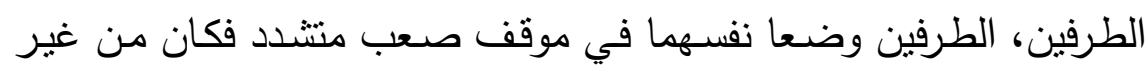

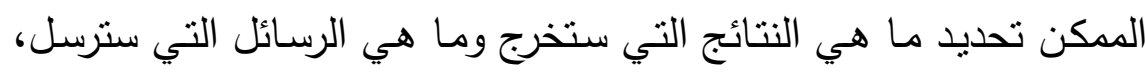

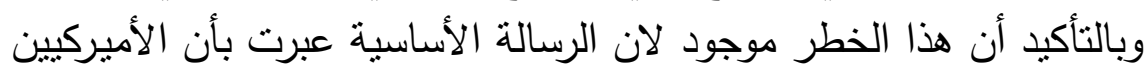

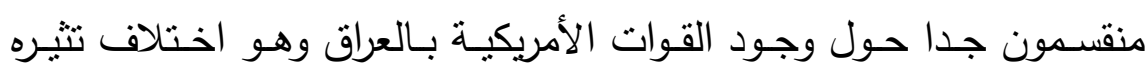
مواقف الحزبين (rr).

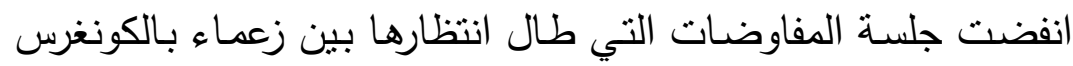

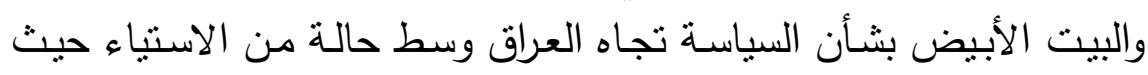

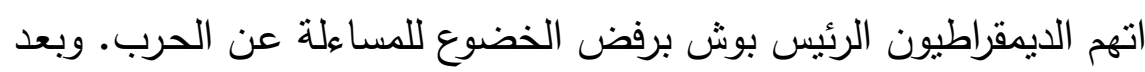

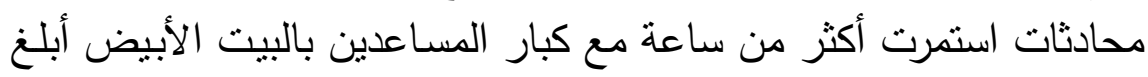

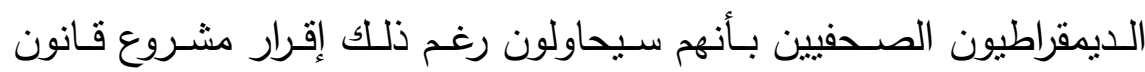


$[r \varepsilon \vee]$

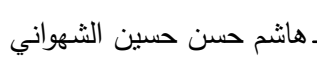

لتمويل القوات الأميركية في العراق وأفغانستان. وقال (هاري ريد) زعيم

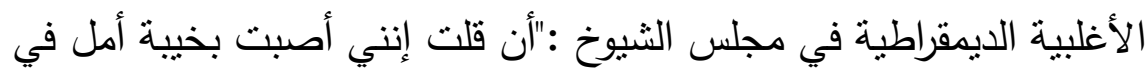

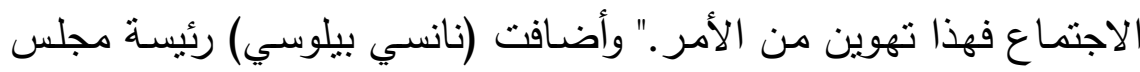

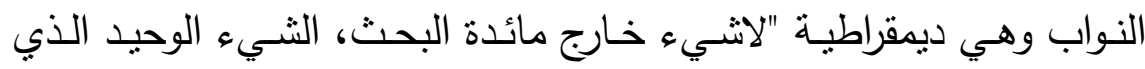

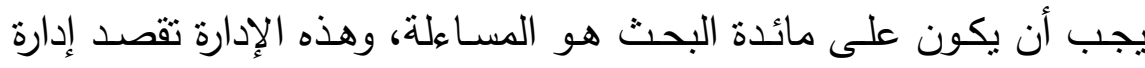

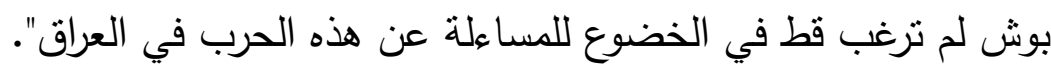

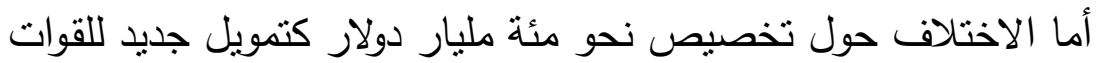

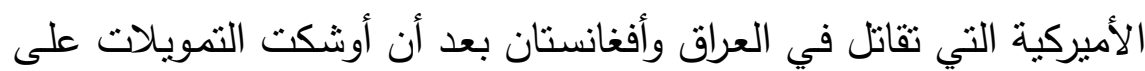

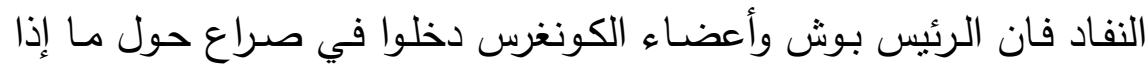

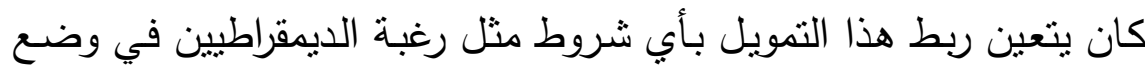

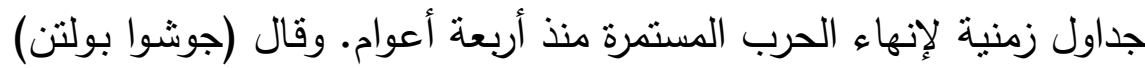

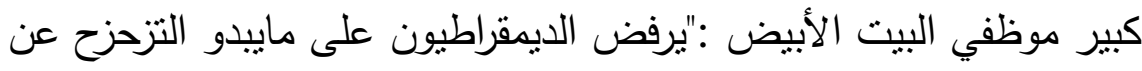

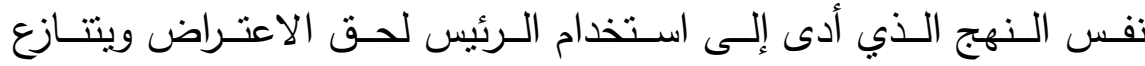

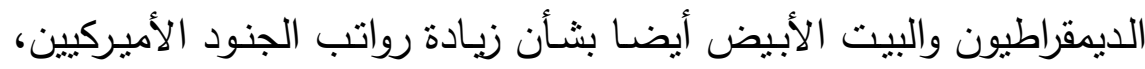

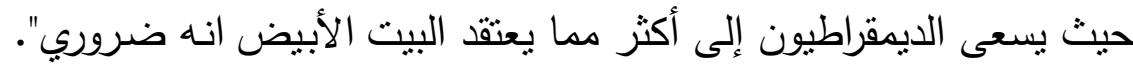

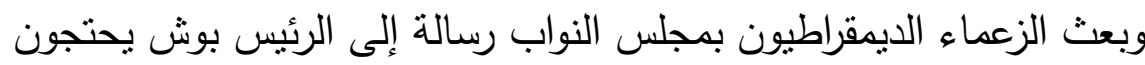

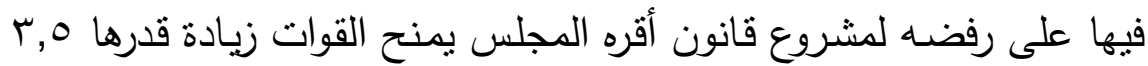

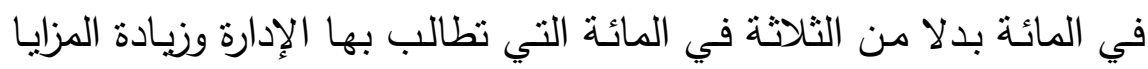

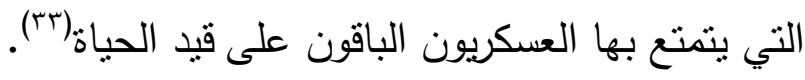
يواصل الديمقراطيون حملتهم للحد من وجود القوات الألئ الأميركية في العراق، من خلال تتريعات في الكونغرس الذي سيطروا عليه في نوفمبر (تترين

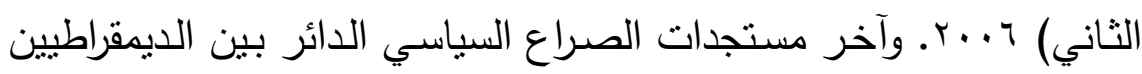

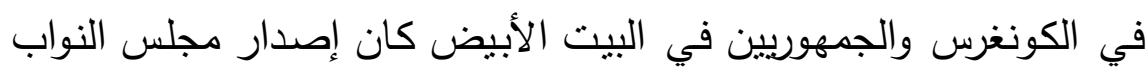

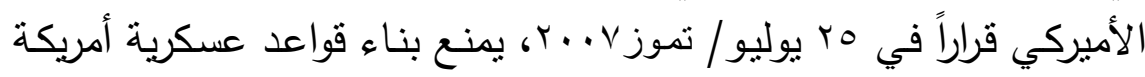

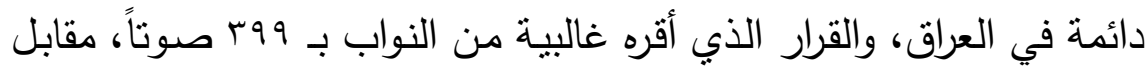


ك كوتا هو تأكيدا من المشرعين الأميركيين بأن لانية لبلادهم بوجود دائمي

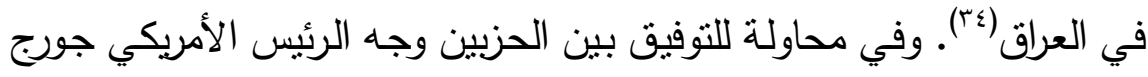

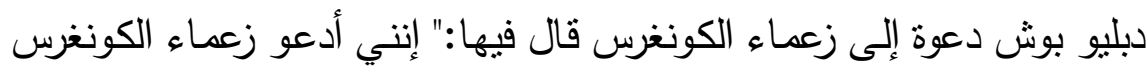

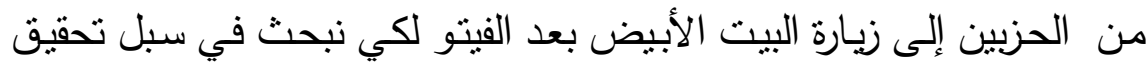
تقدما في هذه المسألة"("ن).

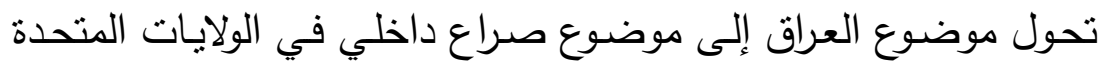

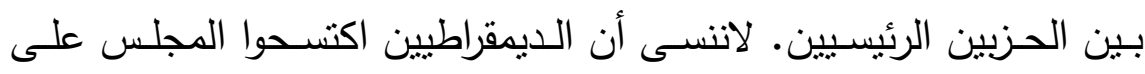

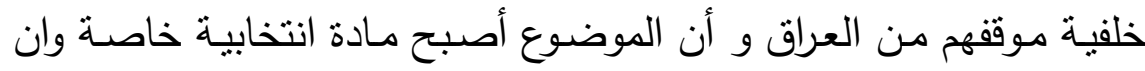

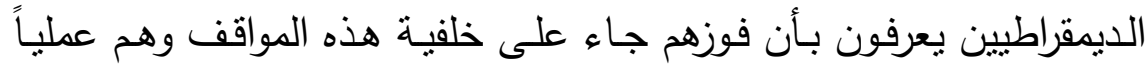

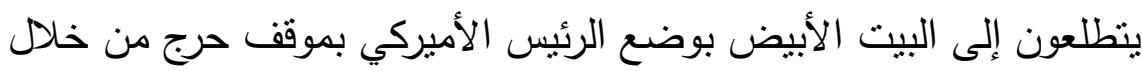

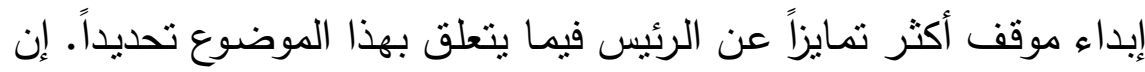

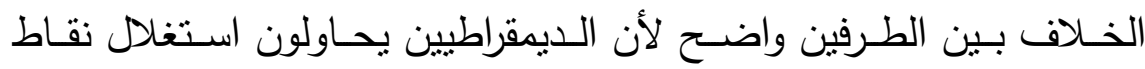

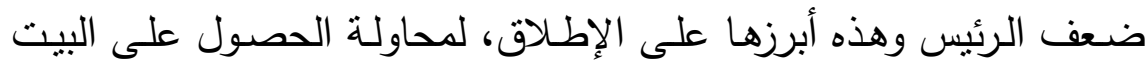

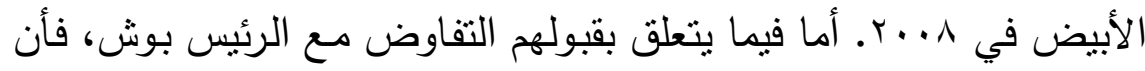

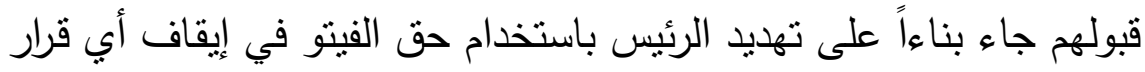

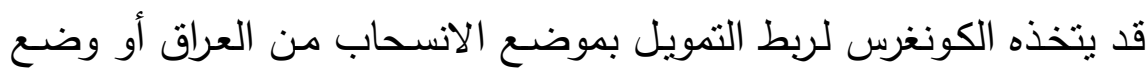
جدول زمني لذلك ("T).

\section{صلاحيات الرئيس الاستورية}

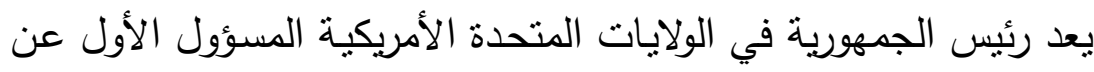

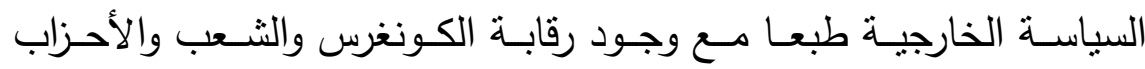
السياسية، وهناك بعد ذللك الأجهزة الحكومية المسؤولة عن التخطيط والتتفيذ

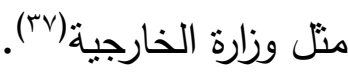

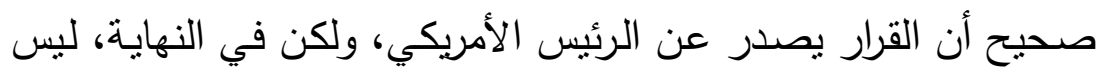

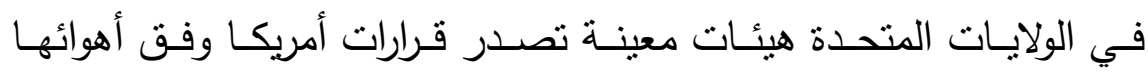


$[r \leqslant 9]$

وأمزجتها، وإنما تتحكم في ذللك مجموعة المصالح الكبرى للولايات المتحدة إندان

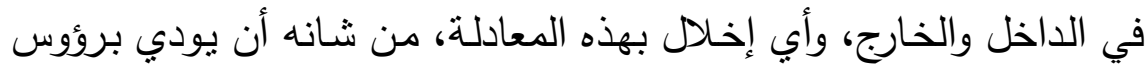

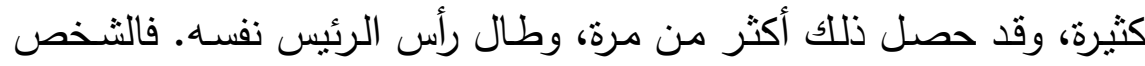

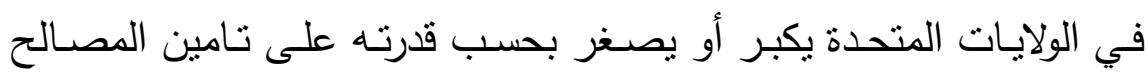

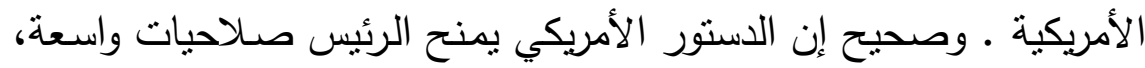

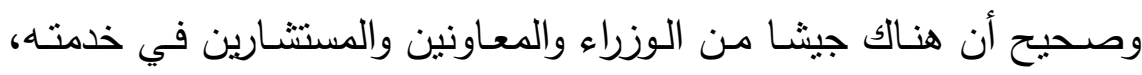

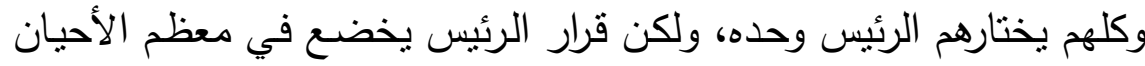

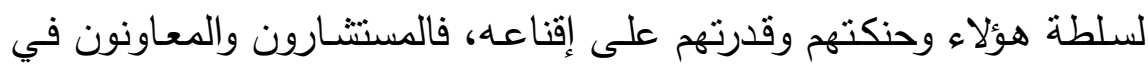

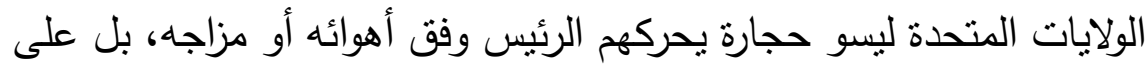

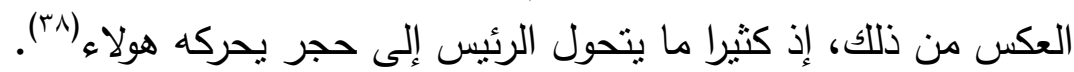

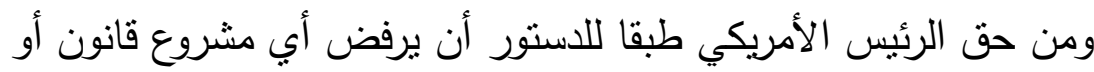

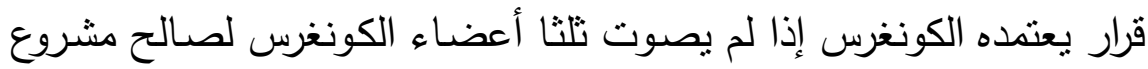

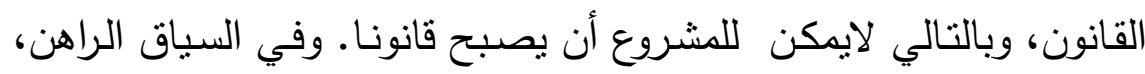

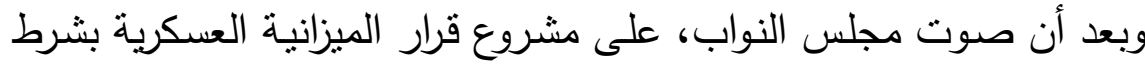

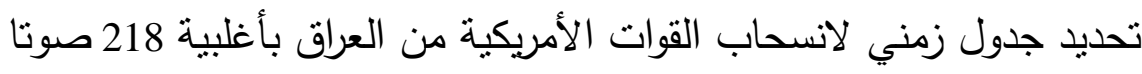

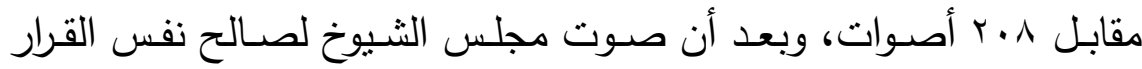
بنتيجة إن صوتا ضد بـ صوتا، فإن نسبة التلثين لم تتحقق. وقد اعتبر

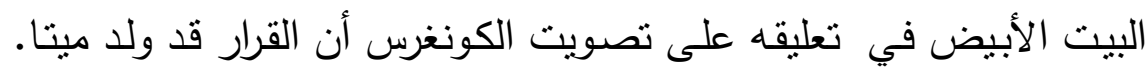

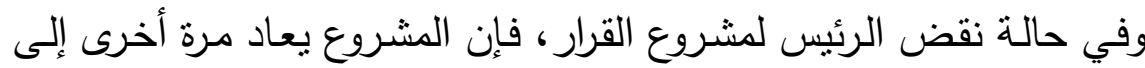

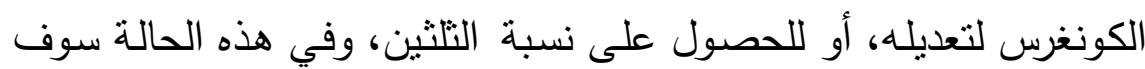
يتخذ الرئيس إجراءات مؤقتة للحصول على التى التمويل (ª).

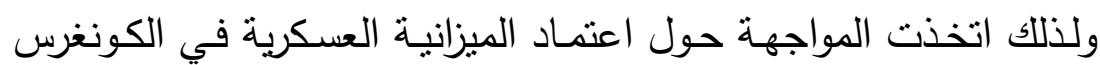

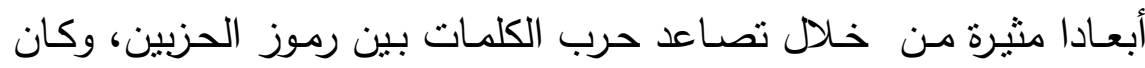
أكثرها إثارة وصف نائب الرئيس الأمريكي (ديلك تنشيني) لزعيم الأغلبية

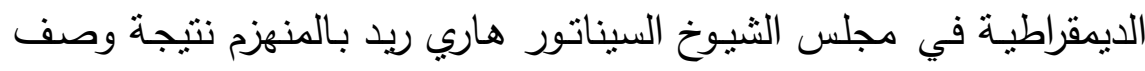


الأخير مؤخرا للحرب في العراق بأنها حرب خاسرة. وفي المقابل ورغم أن

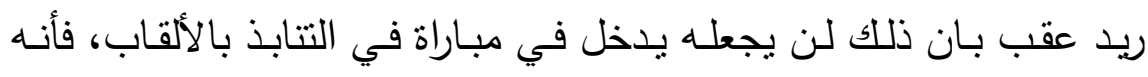

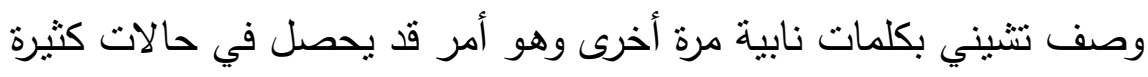

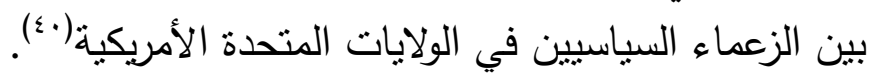

هناك مؤشرات يمكن ملاحظتها حول موضوع العلاقة بين الكونغرس

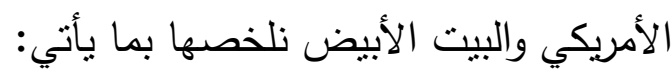

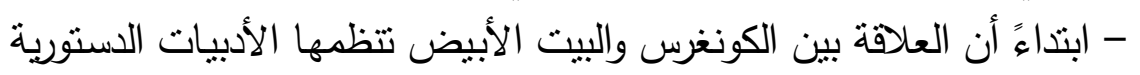

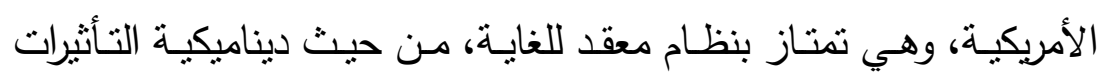

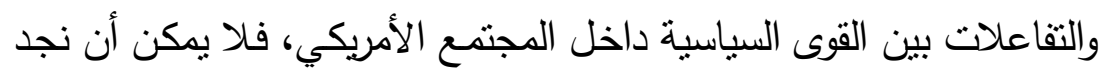
إطارا رسميا لهذه التقاعلات، كما يحلث في دول أخرى.

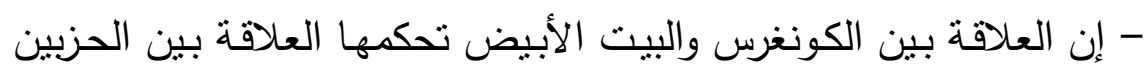

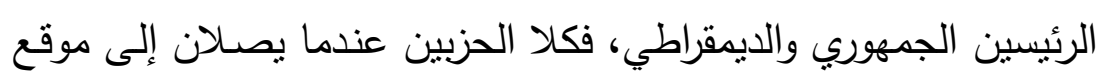

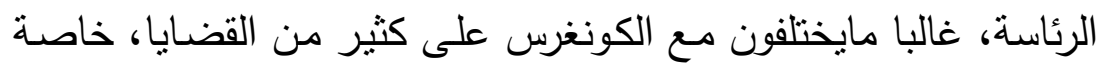

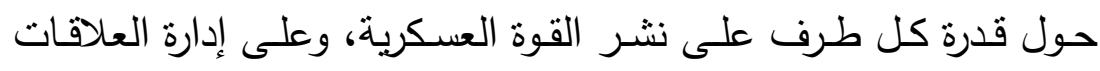

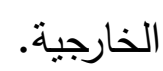

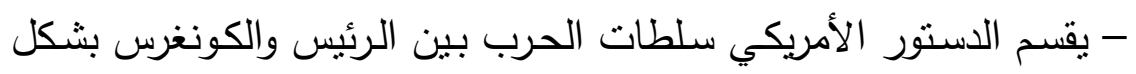

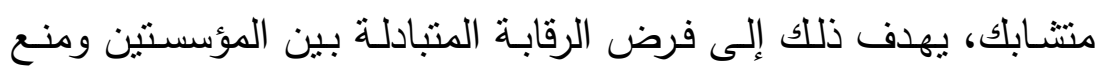
انفراد أحدهما بالسلطة. 
- منح الدستور الأمريكي الرئيس صلاحيات واسعة في أوقات الحروب على الحئ

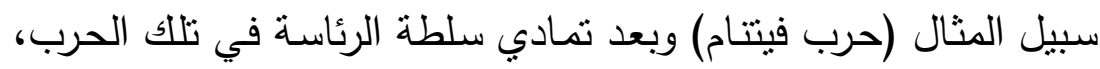

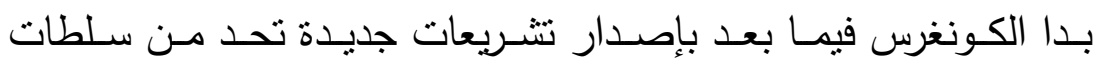
الرئيس، خوفا من الانفراد في السلطة.

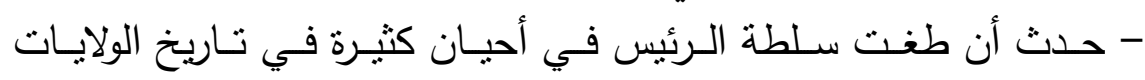

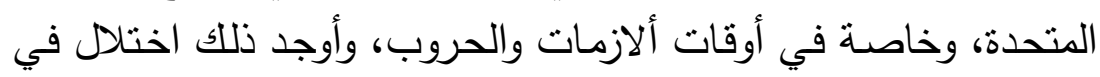

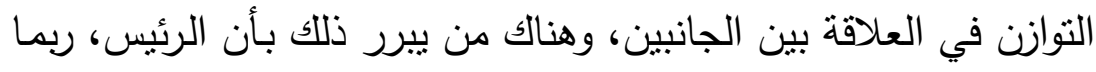

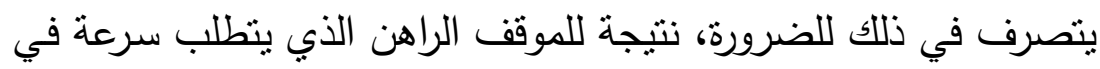

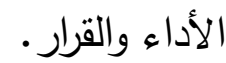
- رغم حدوث هذا الاختلال في التوازن في العلاقة بين الجانبين في فترات

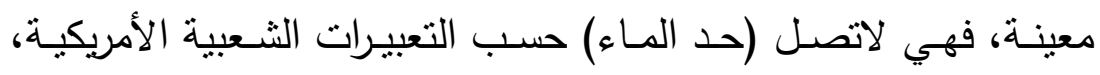

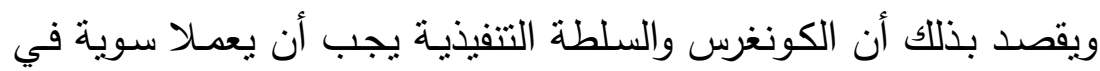

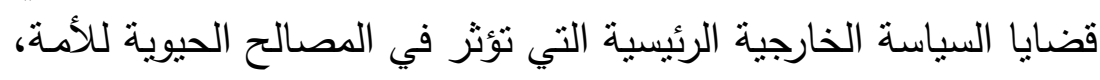

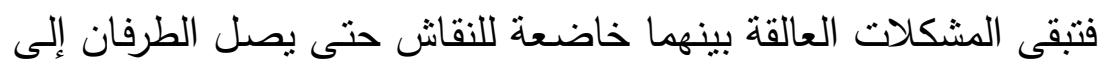

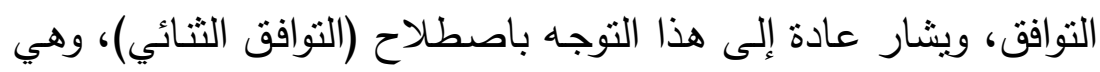
القاعدة المعول عليها دائما لدى الأمريكيين.

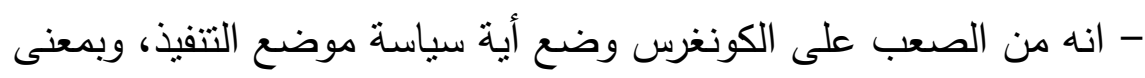

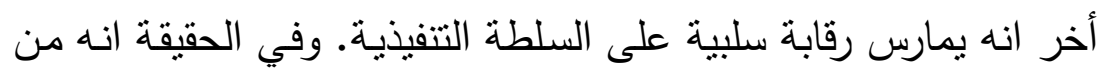

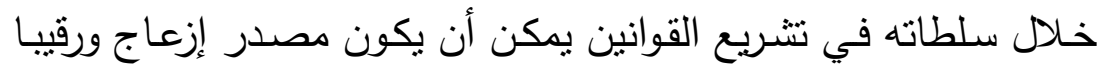
على السياسات، ولكنه نادرا ما يقود أو يقوم بأية مبادرة سياسية الكية مهمة. ومعنى ذلك أن فعالية الكونغرس تكمن في قوته السلبية وليس الايجابية الكابية

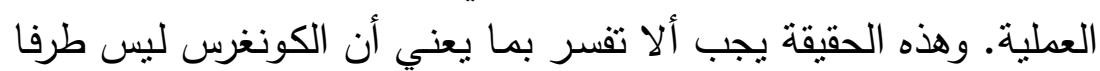
مهما في الثؤون الخارجية.

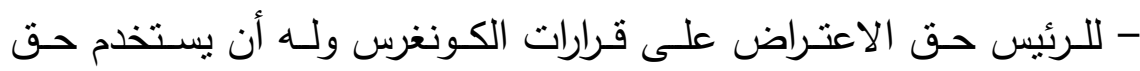

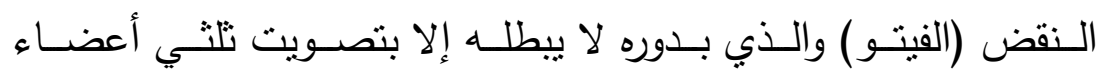




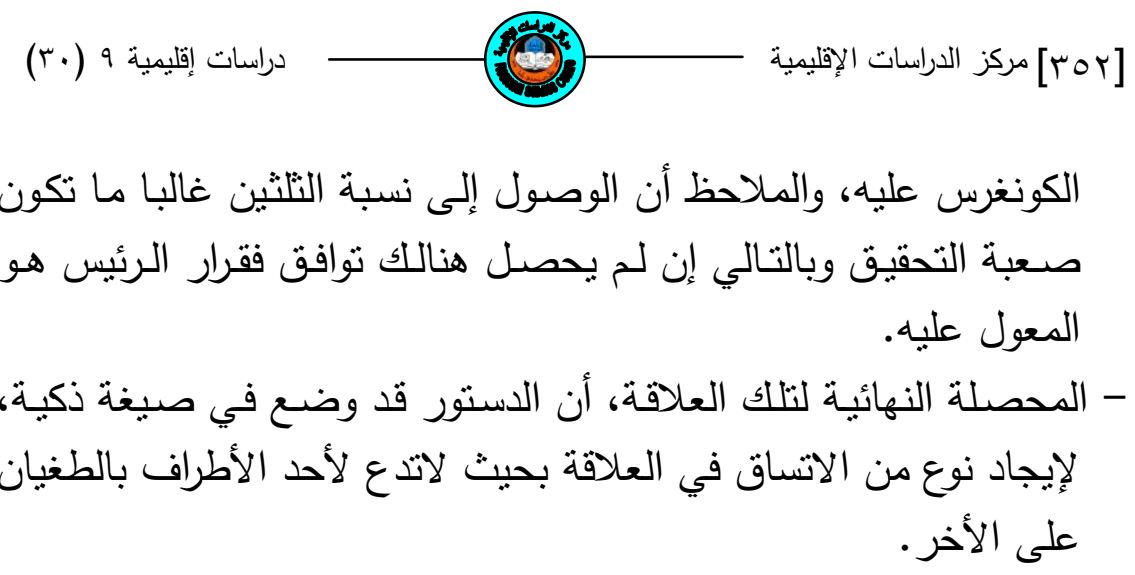

\title{
Relation between Congress And White House Under Foreign Relations
}

\author{
By,Mr Hashim Hasan
}

\begin{abstract}
Many factors determined the relation between the Congress and the White House, such as the relation between the republican and the democratic parties who established rules of political actions practicing, and then the lobbies that reflect economic, political and religious interests, Also human rights groups and environment defenders. May be the most important factor is the constitution which granted the Congress and the president variable responsibilities and authorities in foreign relations field, especially war waging. Often, there were disputations about were the war declaration decision must start?

The American constitution authorized the president to wage war as the supreme commander of military forces, whereas the Congress is authorized to declare and finance war. Therefore the relation between the two parts
\end{abstract}


relating the foreign causes is distinguished with a type of relative balance, so connection between the president and the Congress resolutions was the distinctive mark

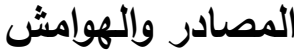

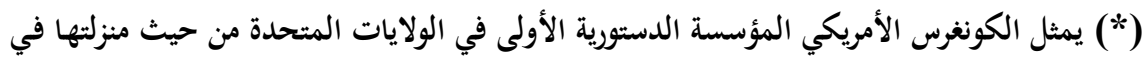

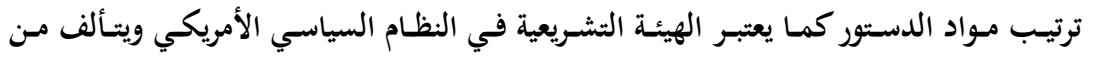

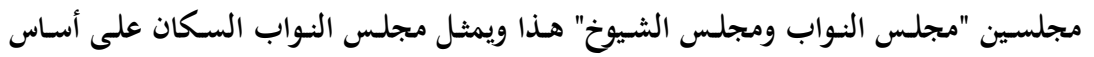

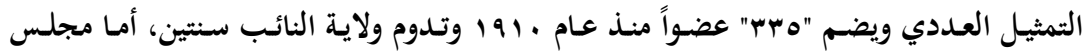

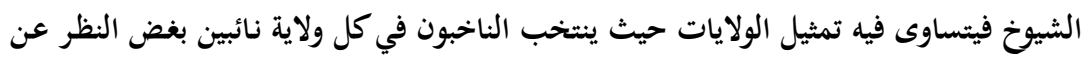

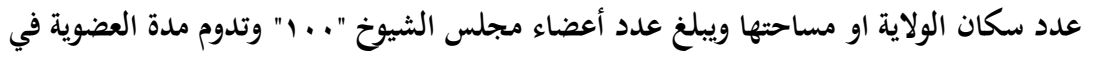

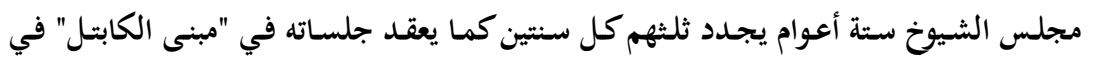

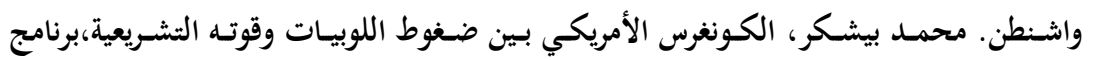
مختارات برامج العالم، شبكة المعلومات العالمية، متاح على الموقع التالي: http;//www.alalam.ir/site/mokhtarat/emperatorsades5.htm.

(1) دريد صكبان: الفدرالية تاريخ ... وعبر، شبكة المعلومات العالمية، متاح على الموقع التالي: http://www.geocities.com/belahdood/Sagban1.htm

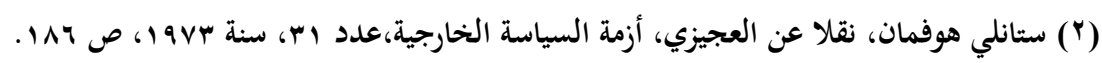

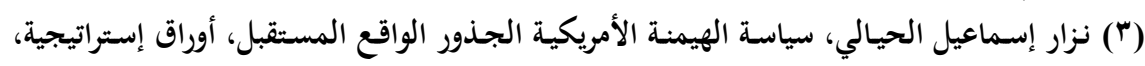

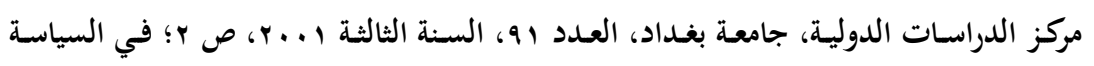

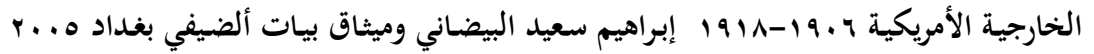


(؛) عبدالعزيز العجيزي، "الكيفية الجديدة لصسناعة السياسة الخارجيـة الأمريكية"، مجلة السياسة

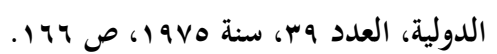

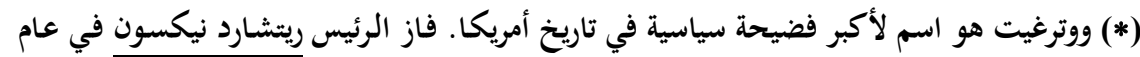

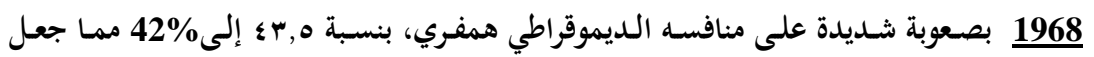

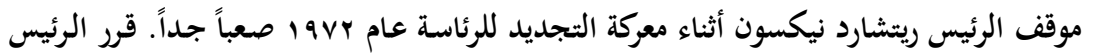

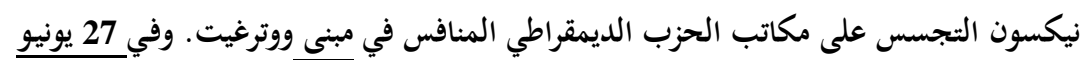

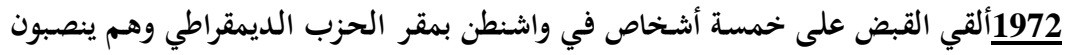

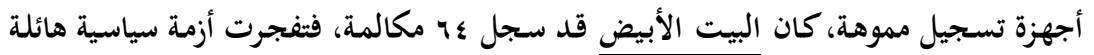

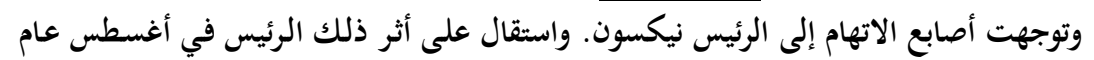

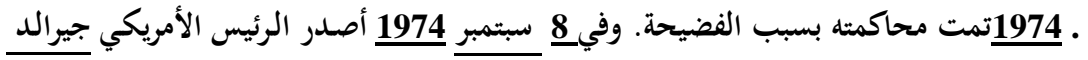

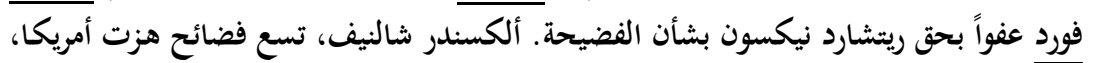

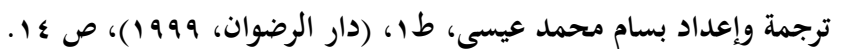

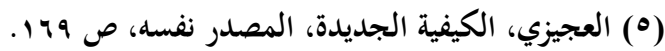

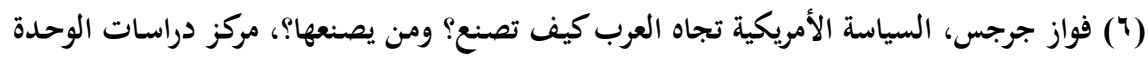

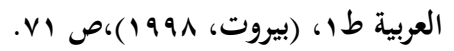

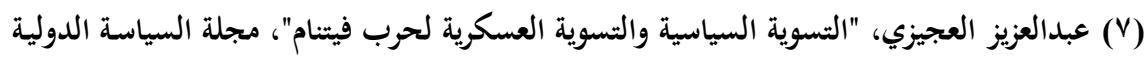

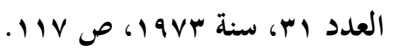

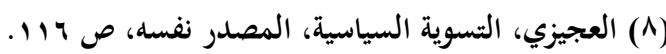

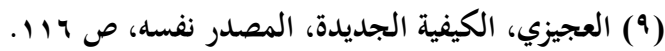

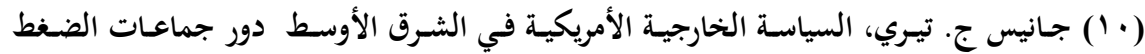

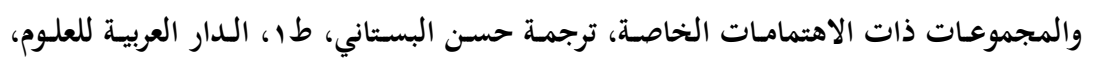

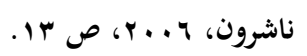$$
\text { (11) }
$$

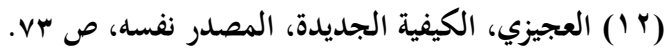

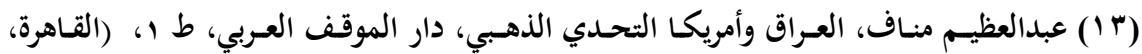
. \&1 ص ص)(1999

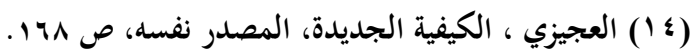

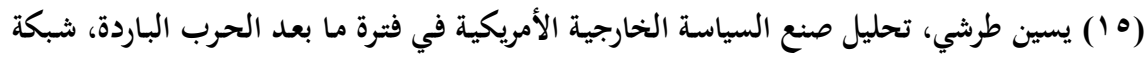
المعلومات العالمية، مثتاح على الموقع التالي: 
[roo]

هاشم حسن حسين الثهواني

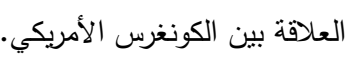

http;// yacien. Maktoobblog.

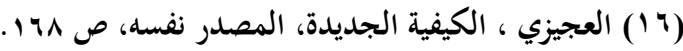

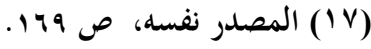

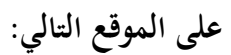

(1^) طلحة جبريل الكونغرس يمنع بناء قواعد دائمة في العراق، شبكة المعلومات العالمية، متاح

http://www.akhbaar.org/wesima_articles.

(9 1 ) الرئيس بوش يطالب الكونغرس بإقرار موازنة دفاعية طارئة لتمويل العمليات العسكرية ضد

$$
\text { الإرهاب، شبكة المعلومات العالمية، متاح على الموقع التالي: }
$$

http://www.radiosawa.com/arabicnews.aspx? Id

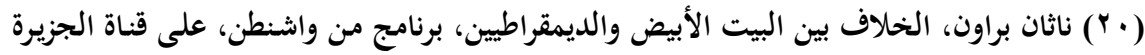

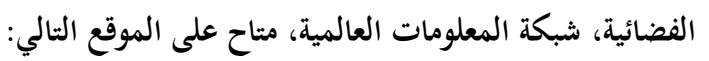

http://www.aljazeera.net/NR/exeres/5CE3A63D-E1F8-464E-

$$
\text { (Yl) }
$$

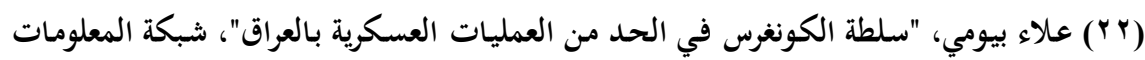

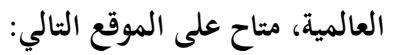

http://www.aljazeera.net

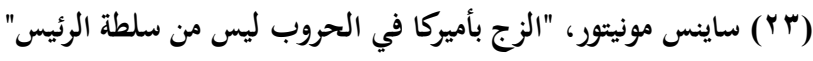

.http://www.aljazeera.net/NR/exeres/IFCDO9BI-7676

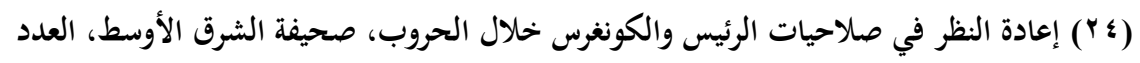

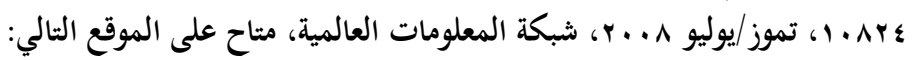

http://www.asharqalawsat.com/leader.asp?

$$
\begin{aligned}
& \text { (Yo) جرجس، المصدر السابق، ص VTr. VT. }
\end{aligned}
$$

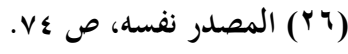

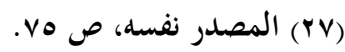

$$
\begin{aligned}
& \text { (Y^) الكونغرس الأمريكي يقاضي البيت الأبيض بسبب إنرون، شبكة المعلومات العالمية، متاح على المعلى }
\end{aligned}
$$

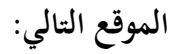

http://arabic.people.com.cn/200202/25/ara.:

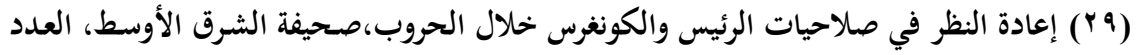

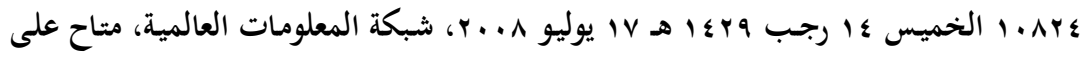

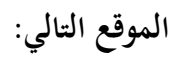


http://www.asharqalawsat.com/leader.asp?section

$$
\text { (T·) مروان قبلان، جريدة الوطن السورية، شبكة المعلومات العالمية، متاح على الموقع التالي: }
$$

http://www.alwatan.sy/dindex.php?idn=32348

$$
\text { (آl) علي حسين باكير، معركة الصلاحيات بين الرئيس الأمريكي و الكونجرس، شبكة المعلومات }
$$

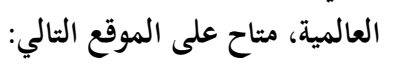

http://alibakeer.maktoobblog.com/348004

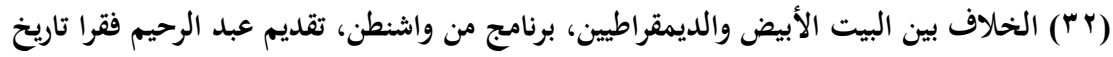

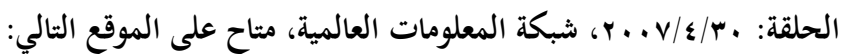

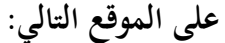

http://www.albawaba.com/ar/news/

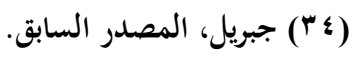

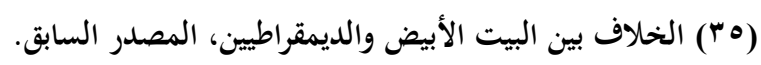

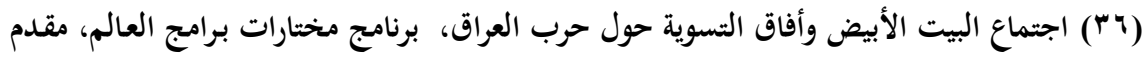

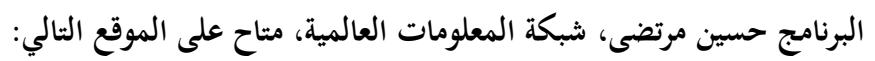

http://www.alalam.ir/site/mokhtarat/Maalhadas/Maalhadas263.htm

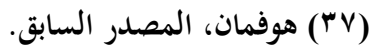

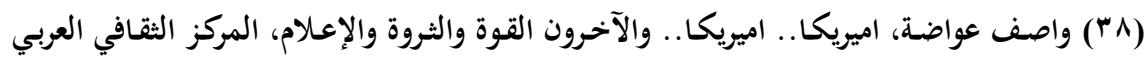

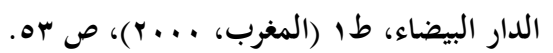

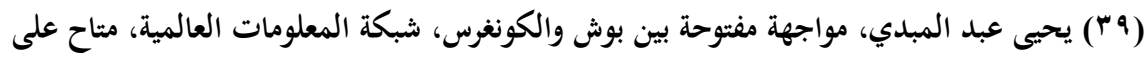

$$
\text { الموقع التالي: }
$$

.saudiinfocus.com/ar/forum/archive/index.pfp?t-33485.htm http://www

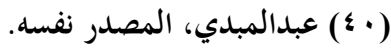


[rov] هاشم حسن حسين الثهواني 
دراسات إقليمية 9 (r)

[ro人] [ مركز الدراسات الإقليمية 